
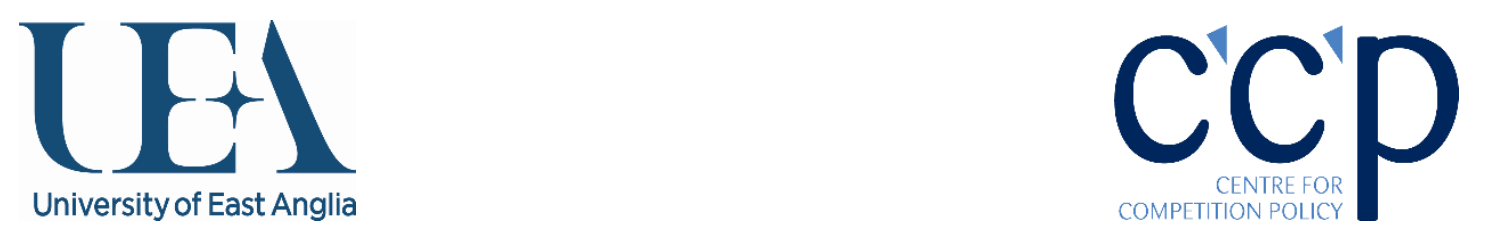

\title{
Do Retailers Manipulate Prices to Favour Private Label over Brands?
}

\author{
Ratula Chakraborty \\ Centre for Competition Policy \\ Norwich Business School \\ University of East Anglia \\ CCP Working Paper 18-2
}

\begin{abstract}
Retailers act as both customers and competitors for brand manufacturers when selling private label in direct competition with brands. This paper considers whether retailers exploit this double-agent position to practice switch marketing, manipulating elements of the retail marketing mix to encourage shoppers to switch from buying brands to private label. Such manipulation can be blatant in nature, such as comparative advertising, brand delisting trials, copycat packaging, and biased shelf allocation. However, the key interest in this paper concerns whether retailers use a more subtle means through strategic pricing to favour private label over brands. The paper reveals very different price treatments of brands and matching private label goods. However, the identified pricing patterns are more indicative of retailers manipulating prices for the sake of segmenting consumers rather than displacing brands.
\end{abstract}

Contact Details:

Ratula Chakraborty

r.chakraborty@uea.ac.uk 


\title{
Do Retailers Manipulate Prices to Favour Private Label over Brands?
}

\author{
Ratula Chakraborty \\ Centre for Competition Policy \\ University of East Anglia
}

CCP Working Paper 18-2

\begin{abstract}
Retailers act as both customers and competitors for brand manufacturers when selling private label in direct competition with brands. This paper considers whether retailers exploit this double-agent position to practice switch marketing, manipulating elements of the retail marketing mix to encourage shoppers to switch from buying brands to private label. Such manipulation can be blatant in nature, such as comparative advertising, brand delisting trials, copycat packaging, and biased shelf allocation. However, the key interest in this paper concerns whether retailers use a more subtle means through strategic pricing to favour private label over brands. The paper reveals very different price treatments of brands and matching private label goods. However, the identified pricing patterns are more indicative of retailers manipulating prices for the sake of segmenting consumers rather than displacing brands.
\end{abstract}

Key words: brand, private label, retailer, pricing, marketing, manipulation J.E.L. codes: K21; L13; L14; L40

Acknowledgements. This paper builds on data developed with Jon Seaton and Paul Dobson and our prior research on switch marketing and I am very grateful for their comments, suggestions and support in taking this research forward.

Corresponding Author: Ratula Chakraborty, Norwich Business School, University of East Anglia, Norwich NR4 7TJ, United Kingdom. Email: r.chakraborty@uea.ac.uk 


\section{Introduction}

The expansion of large-format supermarkets in recent decades has offered opportunities for brands to grow in number, varieties, and sales. Increasingly, though, brands have come under competitive pressure from retailers keen to promote private label and facing budgetconscious consumers less loyal to brands and who are willing to buy private label positioned as a cheaper alternative (Kumar and Steenkamp 2007). As brands lose customer loyalty and sales share to private label then their selling power declines (Steiner 2004). Retailers might then want to encourage shoppers to switch to buying private label, promoting their own goods while also enhancing their bargaining power over brand suppliers. Yet, would retailers go as far as intentionally undermining brands to favour private label? This paper considers this question in terms of how retailers set and adjust the prices of branded goods and their me-too private label equivalents.

Brands have traditionally held an important role for supermarkets, providing familiar products and variety to attract shoppers. However, the development of equivalent-quality private label goods has reduced the need for brands as must-stock items in many categories, with many consumers willing to switch to buying private label equivalents if there is a sufficient cost saving. Accordingly, the price gap between these types of products can be crucial in influencing their respective sales, as might perceptions of the relative value on offer (Steenkamp et al. 2010). Specifically, price levels and the nature of price adjustments may shape reference prices and so influence how consumers perceive whether a brand or its private label equivalent offers better value for money, for given pairs of prices (Dhar and Hoch 1997; Lamey et al. 2012). Thus, by judiciously setting and adjusting prices, a retailer could influence the perceived value for money on offer and steer consumers towards buying private label. This paper considers four different pricing tactics that could achieve this aim. 
At issue is a more general problem for brand owners, caught in a situation where retailers serve as their customers also act as their competitors, in producing private label equivalents. This double-agent position for retailers puts their respective interests in conflict, where brand owners might wish to monopolise category sales but retailers might want to sell private label at the expense of brands (Bell et al. 1997; Dobson 1998). In controlling all the in-store marketing levers, what is to stop retailers undermining brands? There are two possibilities. Firstly, brand owners could apply pressure themselves, such as a boycott threat to withhold supplies, or bribe retailers through extra payments to safeguard sales (e.g. via slotting allowances, overriding discounts, loyalty rebates, or funded price promotions). Even so, the former is only credible if there are alternative routes to market and brand loyalty is stronger than store loyalty (so the brand owner suffers less than the retailer) while the latter might only exacerbate the problem, encouraging retailers to find further ways to undermine brand sales and so extract even higher payments. Secondly, competition amongst retailers might regulate retailers' behaviour, ensuring they price and market brands fairly. However, if they share the same motivation, then they might all adopt the same behaviour, so pricing could be distorted and yet still be competitive overall. In essence, a competitive outcome could have all retailers deliberately steering sales towards private label.

Ultimately, there must be a limit to squeezing brands, otherwise they would not be stocked at all. One reason for continuing to stock brands alongside private label is how they could work in tandem, segmenting brand loyal and switcher consumers (Soberman and Parker 2006; Gabrielsen and Sørgard 2007, Perloff et al. 2012; Dobson and Chakraborty 2014). In this regard, consumers might see the product types as substitutes (choosing one or the other) but the retailer might view them as complements (needing both of them for the purpose of segmenting consumers). Even so, the brand and private label pricing relationship required for effective segmentation might well change as competitive conditions change. 
To examine these issues, this paper analyses the pricing of matched pairs of branded grocery items and private label equivalents across competing retailers over a five-year period in which market conditions distinctly change. The results show that the retailers price private label in a fundamentally different manner to pricing brands. Price correlations between brands and their private label equivalents are only moderate, and price movements for the two product types tend to be noticeably different. The identified pricing patterns for these products are consistent with the view that retailers deliberately treat brand and private label prices differently. In particular, the identified pricing patterns are indicative of retailers manipulating prices for the sake of segmenting consumers rather than displacing brands.

The rest of the paper is organised as follows. Section 2 sets out the conceptual background, reviewing the relevant literature and discussing why and how retailers might favour private label. Section 3 considers how switch marketing may operate through manipulating the pricing of brands and private label equivalents, highlighting four pricing tactics that a retailer might employ to favour private label. Section 4 describes the sample and timeframe for the analysis of matched pairs of branded and private label equivalent goods. Section 5 presents the evidence on the observed pricing patterns. Section 6 concludes the paper by discussing the implications of the findings and suggestions for future research.

\section{Private label favouritism and switch marketing}

The double-agent situation, with a retailer acting as a brand producer's customer and competitor, means that their trading interests will not be aligned (Bell et al. 1997; Dobson and Chakraborty 2009; 2014). The brand producer will want to control category sales while the retailer will want sales for its own private label goods. However, as the gatekeeper to the market, the retailer has the advantage that it controls the retail marketing mix in determining which products it stocks, where to place them, and how to price and promote them (Dobson 
2005). With this control, the retailer could then use the in-store marketing levers to advance its own private label offering even if this comes at the expense of restricting brand sales.

But why should a retailer deliberately favour private label? Bunte et al. (2011) suggest six distinct business advantages for a retailer in favouring private label ("PL") over brands.

Table 1 summarises the reasons behind these six advantages and the relevant literature. ${ }^{1}$

Table 1. Retailer advantages in favouring private label over brands

\begin{tabular}{|c|c|c|}
\hline Source of advantage & Reasons & Literature \\
\hline 1. Higher margins & $\begin{array}{l}\text { Retailer obtains lower supply prices } \\
\text { on PLs by saving on brand marketing } \\
\text { costs and free riding on brand } \\
\text { investments allowing for higher } \\
\text { margins when pricing private labels } \\
\text { just below brands }\end{array}$ & $\begin{array}{l}\text { Higher percentage margins: Hoch and Banerji } \\
\text { 1993; Narasimhan and Wilcox 1998; Raju et al. } \\
\text { 1995; Barsky et al. 2001; Sayman et al. 2002, } \\
\text { Pauwel and Srinivasan 2004; Steiner 2004; } 2009 . \\
\text { Yet, lower absolute margins: Corstjens and Lal } \\
\text { 2000; Ailawadi and Harlam } 2004\end{array}$ \\
\hline $\begin{array}{l}\text { 2. Facilitating } \\
\text { consumer } \\
\text { segmentation }\end{array}$ & $\begin{array}{l}\text { Retailer targets high priced brand at } \\
\text { quality-conscious consumers and } \\
\text { lower priced PL at price-conscious } \\
\text { consumers, using multiple price- } \\
\text { quality tiers to increase category sales }\end{array}$ & $\begin{array}{l}\text { Theory: Wolinsky 1987; Gabrielsen and Sørgard } \\
\text { 2007; Perloff et al. 2012; Dobson and } \\
\text { Chakraborty 2014. Brand prices increasing upon } \\
\text { PL entry: Kim and Parker 1999; Pauwels and } \\
\text { Srinivasan 2004; Ward et al. 2002. }\end{array}$ \\
\hline $\begin{array}{l}\text { 3. Promoting retail } \\
\text { brand to build } \\
\text { consumer loyalty }\end{array}$ & $\begin{array}{l}\text { Retailer uses lookalike PLs to draw } \\
\text { quality inferences from the leading } \\
\text { brands while appearing to offer } \\
\text { increased choice and value }\end{array}$ & $\begin{array}{l}\text { Corstjens and Lal 2000; Sudhir and Talukdar } \\
\text { 2004; Ailawadi et al. 2008; González-Benito and } \\
\text { Martos-Partal 2012; Seenivasan et al. 2015; } \\
\text { Coelho do Vale et al. } 2016 .\end{array}$ \\
\hline $\begin{array}{l}\text { 4. Retailer } \\
\text { differentiation and } \\
\text { reduced price } \\
\text { comparability }\end{array}$ & $\begin{array}{l}\text { Retailer uses its exclusive PLs as a } \\
\text { point of differentiation from rivals, } \\
\text { making it harder for consumers to } \\
\text { make like-for-like price comparisons }\end{array}$ & $\begin{array}{l}\text { Walters and Rinne 1986; Dobson 1998; } \\
\text { Corstjens and Lal 2000; Ailawadi et al. 2008; } \\
\text { Seenivasan et al. } 2015 \text {. }\end{array}$ \\
\hline $\begin{array}{l}\text { 5. Weakening brand } \\
\text { producer's } \\
\text { bargaining position }\end{array}$ & $\begin{array}{l}\text { Retailer uses its PL provides a } \\
\text { credible alternative to counter brand } \\
\text { withholding threats and leverage to } \\
\text { secure more favourable trading terms }\end{array}$ & $\begin{array}{l}\text { Scott-Morton and Zettelmeyer 2004; Lal 1990; } \\
\text { Narasimhan and Wilcox 1998; Sayman et al. } \\
\text { 2002; Ailawadi and Harlam 2004; Meza and } \\
\text { Sudhir 2010; Ellickson et al. 2017. }\end{array}$ \\
\hline $\begin{array}{l}\text { 6. Creating revenue } \\
\text { synergies across } \\
\text { categories }\end{array}$ & $\begin{array}{l}\text { Retailer leverages PL success in one } \\
\text { category to encourage consumers to } \\
\text { experiment with PL in other } \\
\text { categories }\end{array}$ & $\begin{array}{l}\text { Sayman and Raju 2004a (positive umbrella } \\
\text { effect); Chintagunta } 2002 \text { (under-pricing PL to } \\
\text { maximise PL share); Sudhir and Talukdar (2004) } \\
\text { (loyalty and differentiation benefits relate to the } \\
\text { PL range breadth). }\end{array}$ \\
\hline
\end{tabular}

Given that the retailer might have strong motives to favour private label over brands, it is natural then to consider how it could operate this favouritism. To the extent that retail

\footnotetext{
${ }^{1}$ See also Bergès-Sennou et al. 2004; Sayman and Raju 2007; Pauwels and Srinivasan 2009; Sethuraman 2009; Hyman et al. 2010; Sethuraman and Raju 2012; Sethuraman and Gielens 2014; Dobson and Zhou 2014.
} 
competition allows for some flexibility, the retailer has at its disposal control over all "4 Ps" in the marketing mix to influence purchasing decisions and, if it so chooses, encourage consumers to switch to buying private label instead of brands (Meza and Sudhir 2010). To illustrate how extensive are the possibilities, Table 2 shows for each of the 4Ps a range of switch marketing tactics, some quite blatant and others more subtle, along with examples in practice.

Table 2. Retailer switch marketing tactics to favour private label over brands

\begin{tabular}{|c|c|c|}
\hline Variable & Switch Marketing Tactics & Retailer examples \\
\hline & $\begin{array}{l}\text { - influence consumers' product choices by } \\
\text { controlling the product range stocked } \\
\text { - develop me-too and copycat PL with very } \\
\text { similar formulation and packaging to } \\
\text { established brands } \\
\text { - use advanced brand design knowledge to } \\
\text { introduce or reposition private label } \\
\text { equivalents } \\
\text { - provide multiple PL quality tiers (budget, } \\
\text { standard, and premium) to flank and squeeze } \\
\text { brands; } \\
\text { - delist weaker brands and brand variants }\end{array}$ & 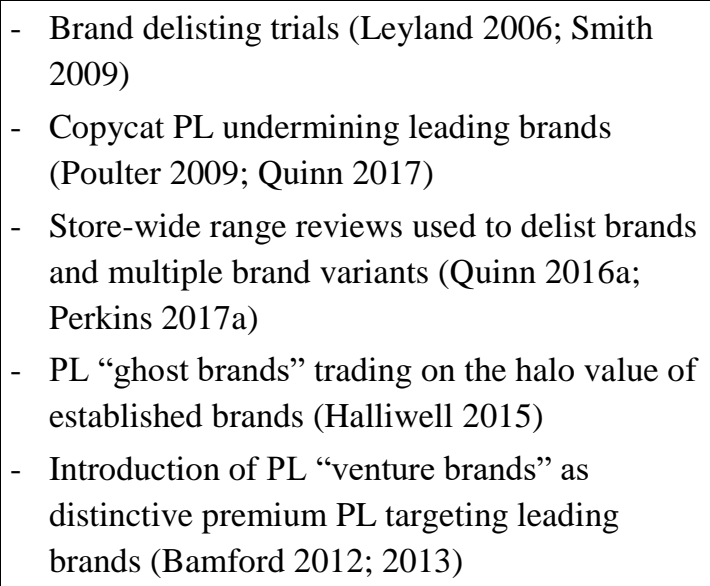 \\
\hline Price & $\begin{array}{l}\text { - price lookalike PL just below brand price to } \\
\text { signal quality equivalence } \\
\text { - widen the price gap to give PL the appearance } \\
\text { of better value for money } \\
\text { - juggle brand prices to alter consumers' } \\
\text { perceptions about their underlying value and } \\
\text { worth }\end{array}$ & 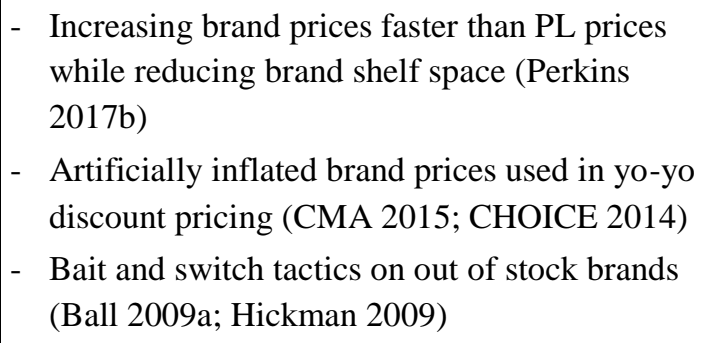 \\
\hline Place & $\begin{array}{l}\text { - influence consumers' accessibility to products } \\
\text { through control of in-store product placement, } \\
\text { shelf allocation and number of facings } \\
\text { - shelve lookalike PLs adjacent to brands to } \\
\text { suggest quality equivalence } \\
\text { - charge brands (but not PL) slotting allowances } \\
\text { for prominent display space with high footfall }\end{array}$ & $\begin{array}{l}\text { - Favourable shelf space allocation for PL } \\
\text { (Fernandez Nogales and Gomez Suarez 2005) } \\
\text { - } \text { Using range reviews to remove brands and } \\
\text { increase shelf space for PL (Quinn 2016b) } \\
\text { - } \text { Increasing shelf space fees for brands } \\
\text { (Economist 2015) } \\
\text { - }\end{array}$ \\
\hline Promotion & $\begin{array}{l}\text { - direct consumers' attention to PL through in- } \\
\text { store advertising, displays and taste tests } \\
\text { - use mass media advertising campaigns } \\
\text { ("switch and save"), targeted advertising ("see } \\
\text { cheaper alternative!"), and personalised } \\
\text { marketing (e.g., using loyalty card data) to } \\
\text { shift demand to PL } \\
\text { - give vouchers and coupons to buy PL }\end{array}$ & $\begin{array}{l}\text { - Compare and save campaigns in the US (Voge } \\
\text { 2004; Gates 2008), Australia (Palmer 2009), } \\
\text { Germany (Olbrich et al. 2009) and UK } \\
\text { (Leyland et al. 2008; Grocer 2009) } \\
\text { - } \text { PL vs brand blind taste tests (Gallagher 2008; } \\
\text { Grew 2009) } \\
\text { - } \text { Coupons and giveaways for PL when buying } \\
\text { brands (Tarnowski 2004; Gates 2008) }\end{array}$ \\
\hline
\end{tabular}


Switch marketing, with the kinds of practices listed in Table 2, is far from a new phenomenon. Over one hundred years ago, Hurd and Zimmerman (1914, p. 41) wrote about bait and switch tactics where aggressive retailers would use nationally advertised goods as 'leaders' and pay their clerks premiums to switch customers to private brands or 'long-shot' goods when the customers asked for an advertised brand. However, it is really in the last two decades that pushing consumers towards buying private label instead of brands has come to the fore as retailers have extended their PL ranges with multiple quality tiers and multiple variants to rival the leading brands (Kumar and Steenkamp 2007).

The squeeze on brands has been particularly noticeable in Europe over recent years, where private label has rapidly increased its share, to the point where it accounts for more than two-fifths of sales in Switzerland, the UK and Spain, and more than a quarter of sales in the majority of EU countries (Nielsen 2014). The squeeze has mostly profoundly affected secondary and tertiary brands. For example, in the UK, while private label accounts for $41 \%$ of sales, a similar level at $40 \%$ comes from the category leader, leaving only $19 \%$ from all other brands. In contrast, in the U.S., the retail market is much less concentrated and private label growth has been slower, with only $17 \%$ of sales coming from private label, $31 \%$ by the category leader, and 52\% from all other brands (Nielsen 2014). Nevertheless, even in the U.S., private label appears to be advancing at the expense of brands, especially as retailers specialising in private label, like Costco, Aldi, Trader Joe's, expand their store networks and online sales, encouraging retail rivals to focus more on private label sales (Stores 2018).

As the examples in Table 2 highlight, retailers may be quite open in favouring private label and challenging the position of brands. For instance, retailers might conduct high profile delisting trials, temporarily delisting individual brands and only reintroducing them if there is a discernible drop in trade in that category. Blatant favouritism towards private label also comes from advertising and promotional campaigns specifically encouraging consumers to switch 
from buying more expensive brands to cheaper private label, featuring slogans like "compare and save" and "switch and save". Retailers might also intentionally develop copycat private labels, directly imitating leading brands in respect of their formulation, packaging, and appeal, and thereby free riding on the image and goodwill that brands have built up through their product and marketing investment. Other ploys that retailers might use include giving favourable shelf space allocation, by awarding private label with a greater number of facings and mid-shelf, eye-level placement as well as special product displays.

However, there are limits to how far retailers might want to be seen openly undermining brands, which have considerable value to consumers and so puts the retailer at risk of losing sales if it goes too far in reducing the presence or attraction of buying brands. Also, brand producers can be expected to fight back, using advertising to connect with consumers to build brand loyalty, threatening retailers with withdrawal of promotional support, and taking legal action against copycats to protect against infringements of intellectual protect rights. Rarely, though, will brand producers go as far as to withhold supplies or boycott a retailer, where a trade war is likely to be harmful to both sides unless the brand is a true must-stock product such that consumers will shop elsewhere to buy. ${ }^{2}$

While consumer loyalty to primary brands offers some protection, secondary or tertiary brands appear much more vulnerable and at greater risk of being replaced by private label. Nevertheless, there are more subtle means that retailers might use to favour private label over all types of brands and that comes through the retailer's control over retail pricing. The next section considers different approaches to strategic pricing that could favour private label as a prelude to the empirical analysis examining pricing behaviour for a matched-pairs sample.

\footnotetext{
2 As an example, see Benady (2009), but this is an extreme instance that involved the delisting of 250 Unilever products by the retailer, so restricted choice across a wide number of product categories.
} 


\section{Strategic pricing favouring private label}

While retailers may seek to adopt quite open or blatant discrimination in favour of private label through product selection, placement, and promotion, there is also the option to adopt strategic pricing as a perhaps more subtle form of private label favouritism, at least to the unassuming consumer if not the brand producer observing sales or margins slide. This relies on the retailer having some latitude over the item-level prices it can set, which could reasonably apply in a multiproduct retailing context where shoppers purchase a bundle of goods as a basket rather than single items (Bliss 1988; Thomassen et al. 2017; Armstrong and Vickers 2018).

Meza and Sudhir (2010) suggest that strategic pricing might occur as just a temporary phase, allowing a new private label to build up market share and critical economies of scale before the retailer goes back to category profit maximising pricing. However, it is conceivable that a retailer may be interested in playing a longer game of advancing the position of private label or using strategic pricing as a "slow burning" effect in shaping consumer price expectations, and in the process their quality perceptions and buying behaviour, as a gradual process over time. For instance, Chintangunta's (2002) empirical results are consistent with the view that the retailer may take a longer-term perspective in building up private label at the individual category level as this can help facilitate private label expansion into other areas.

In taking a perspective that a retailer may wish to build private label volume or extract greater category revenue from more effective consumer segmentation and price targeting, there are four particular pricing tactics that the retailer might find useful in developing over time to raise sales of a me-too private label at the expense of an imitated brand:

1. “Rip-Off Brand" tactic - The retailer raises brand prices to such a level as to choke off demand encouraging consumers to switch to the less costly, better value own label, while capturing increased surplus from those consumers remaining loyal to the brand. 
2. "Private Label Value Champion" tactic - The retailer lowers private-label prices to enhance their perceived value for money and make brands look over priced and poor value, thus more effectively targeting value-conscious consumers.

3. "Same-Quality-But-Better-Value Private Label" tactic - The retailer prices the private label close to the brand to encourage consumers to think they are of equal quality but with the private label offering slightly better value through its slightly lower price as an umbrella pricing tactic.

4. "Dubious Brand Value" tactic - The retailer raises and lower prices of brands in a repeating up-down yo-yo manner to confuse the consumer as to their real value and encourage trial of more consistently priced private label.

Figure 1 illustrates each of these four tactics, showing the relationship between the brand price and its private label equivalent over time. 
Figure 1. Strategic pricing tactics

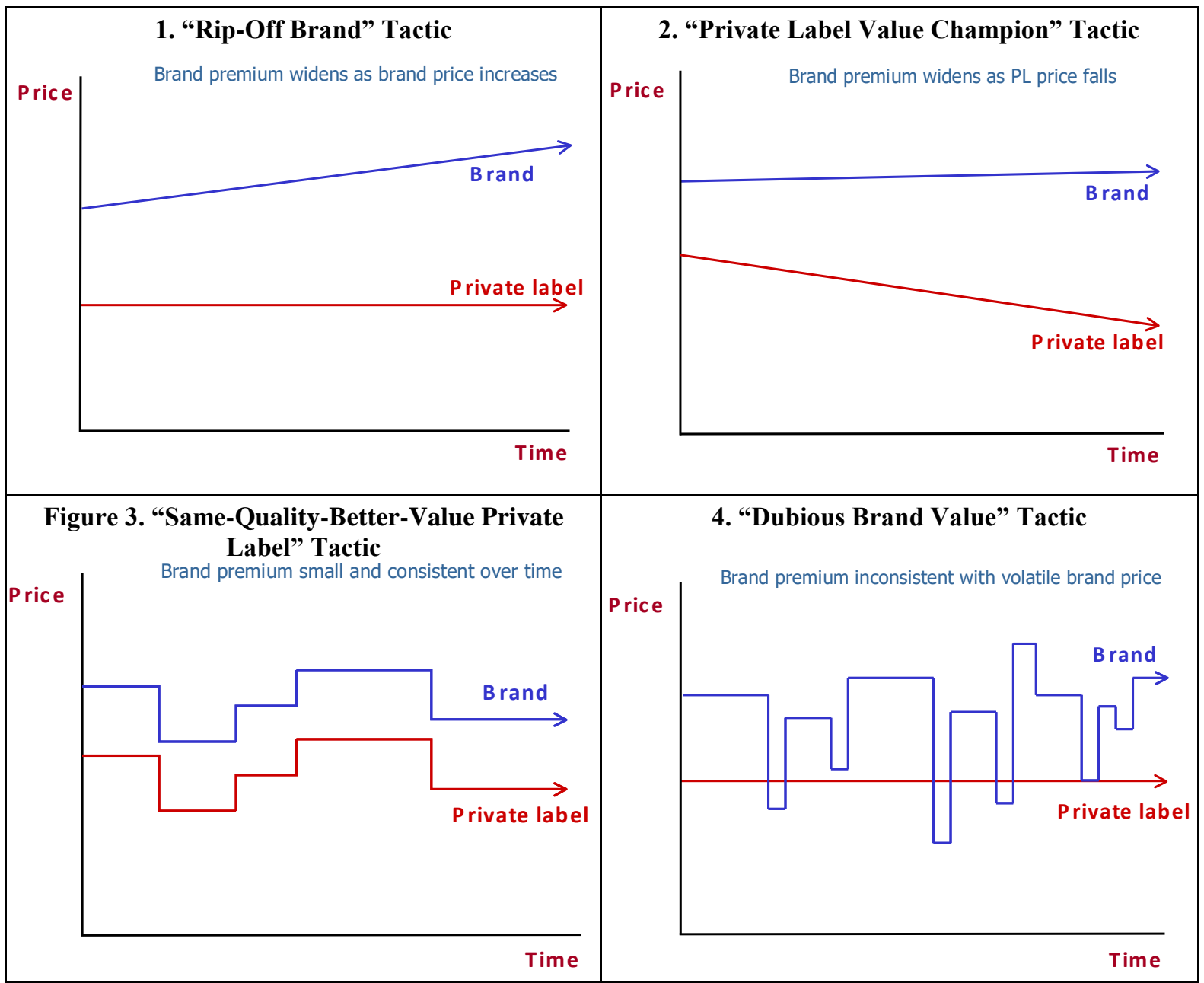

The viability of each tactic is likely to depend on the precise circumstances and nature of the brand and private label products involved. The first two tactics involve the retailer increasing the price gap between the brand and the private label over time. In the former case, the retailer raises the brand price while holding the private label price constant. This may be an attractive option when it allows the retailer to capture more surplus from heavily advertised brands with loyal consumers (e.g. Kim and Parker 1999; Bonfrer and Chintagunta 2004; Soberman and Parker 2006). As Kumar and Steenkamp (2007, p. 104), Meza and Sudhir (2010) and Ezrachi and Reynolds (2009) note, though, price transparency across retailers and consumers willing to shop around for the lowest prices may limit the extent of this tactic. 
However, if all retailers think similarly then they would all have increased scope for employing the tactic. Accordingly, in employing this tactic, one might expect to see all rival retailers using it on that particular product, and in that way keep the brand's price in step with each other. Close price monitoring and tracking by the retailers may assist this process as they seek to keep prices closely aligned and move in step with each other when making price adjustments.

With the second tactic, the retailer increases the price gap by lowering the private label price, which may be a straightforward penetration pricing tactic, which is consistent with Chintagunta's (2002) results suggesting the retailer uses the tactic to build private label share. The downside is that if consumers view private label across retailers as substitutable then it may exacerbate price competition, which could lead to the private label pricing becoming permanently lower rather than just temporarily so. Accordingly, if retailers are sensitive to rivals setting lower prices on private label, and taking away their mantle as a value champion, then they may respond in equal measure, so one player adopting the tactic may trigger all other players to follow suit. This raises the possibility of all retailers finding themselves stuck in a rut whereby no player wants to be the first to raise prices, unless there is the possibility of a retailer acting as a price leader in raising prices that the others then follow.

The third tactic represents a standard form of umbrella pricing where the retailer shields private label just below the high brand price to earn high margins (e.g. Competition Commission 2000). ${ }^{3}$ In this context, the retailer sets the private label price just below the brand to signal to consumers that the private label quality is near identical to the mimicked brand, even if PL price bears little relationship to the underlying private label cost. Again as a tactic, this is only likely to be sustainable if the rival retailers also adopt the same behaviour, such that

\footnotetext{
${ }^{3}$ The Competition Commission (2000) relates umbrella pricing to the situation in which the price of the national brand "effectively sets an upper limit for the pricing structure of the entire product group" (p. 139). The observation made was that the prices of the own brands do not seem to be based on the marginal costs of the product, but rather pegged to the price of the leading national brand. See also Olbrich and Grewe (2013).
} 
the tactic could break down if one retailer began cutting private label prices to bring them more into line with costs. The tactic could also fail if consumers reject the private label quality inference and see it as inferior to the brand, and in seeking to avoid this possibility then the retailer might purposefully design the private label to mimic the brand as closely as possible in terms of appearance, formulation, and packaging.

The fourth tactic serves to confuse the consumer as to the true value of the brand, and whether it offers good value for money when at one moment it has a very low price and, at the next moment, it has a very high price. The retailer juxtaposes this volatile brand pricing with stable pricing on the private label, which thereby appears to offer more consistent and certain value for money. In a sense, this portrays the difference between the relative attractions of high-low promotional pricing and everyday low pricing, only here carried out in the same store. However, high frequency price discounting can affect consumers' perceptions of the appropriate reference price, which in turn could undermine consumer willingness to pay and adversely affect brand loyalty (Mazumdar et al. 2005). Even if the brand producer recognises that yo-yo prices can damage its brand image, it may be powerless to stop this happening because it cannot restrict the retailer from discounting prices (since most jurisdictions prohibit producers using resale price maintenance and dictating minimum retail prices that retailers must apply). ${ }^{4}$ Indeed, the brand producer may be obliged to contribute to its own problems when it is unable to resist demands from a powerful retailer to fund the big price drops through its promotional support payments to the retailer (Competition Commission 2008, p. 170). This may mean the brand producer pays a high penalty for price cuts that result in loss-making sales, especially when consumers learn to "lie in wait" and only buy the brand when it is on promotion (e.g. Lodish and Mela 2007). For the retailer this makes the tactic very attractive, as the

\footnotetext{
${ }^{4}$ However, there might be exceptions for allowing minimum resale prices in the case of luxury goods that require specialist sales services, e.g. the US case Leegin Creative Leather Products, Inc. v. PSKS, Inc. (2007).
} 
producer effectively pays for the damage to its own brand image while at the same time enhancing the retailer's image in providing bargain offers in its stores.

The empirical analysis in the next two sections considers whether there is evidence for strategic pricing that might correspond to these four tactics and more generally the pricing relationship between brands and corresponding imitation private label goods.

\section{Matched-pairs pricing analysis}

In order to compare directly the treatment of brands with their private label equivalents, this section sets out the data used to analyse prices of matched pairs of branded items and private label equivalents sold over a substantial period. The data relate to prices of the leading four UK grocery retailers over a full five-year period, covering 264 consecutive weeks from late 2003 to late 2008. These "Big 4" grocery retailers - Tesco, Asda, Sainsbury's and Morrisons - jointly account for around three-quarters of all supermarket sales and around twothirds of all grocery sales in the UK over the time period (Competition Commission 2008; Chakraborty et al. 2015).

An attractive feature in studying the UK context is its intensely competitive oligopolistic setting, so retailers will only adopt pricing tactics that ensure prices remain competitive with those of rivals, or otherwise risk losing market share. In addition, comparing the prices of the Big 4 retailers is straightforward in this UK context since they practice uniform national pricing, so that an item has the same price across the retailer's entire superstore network throughout the whole country (Competition Commission 2008). Furthermore, all four of these retailers have very sophisticated private label programmes, and each is very capable of developing private label products that can challenge the product quality of the leading brands in almost all product categories (Mintel 2009). Moreover, all four retailers have remarkably similar private label shares, accounting for close to half all their grocery sales by the end of the 
study period (Nielsen 2009). (Table A1 in the Appendix provides further details on the sales performance of the four retailers).

The source of the price data is the body of pricing data published online by Tesco for its "Pricecheck" price comparison service made publicly available and which we downloaded weekly over a full five-year period running from 10 November 2003 to 24 November 2008 (after which the service ceased). The Pricecheck price comparison service provided weekly updated price comparisons across the leading four supermarket retailers on a very wide range of grocery items. A number of other studies have also used this data source for pricing analysis, including Wildenbeest (2011), Seaton and Waterson (2012), and Chakraborty et al. (2014; 2015). However, a primary advantage in the present context is that it is one of the retailers (i.e. Tesco), and not a researcher, that is determining which private label goods are a precise match across each of its three rivals. This is important because it rules out any ambiguity and the potential for misclassification because Tesco would only cite matches when sure that its rivals' private label goods were a close match to its own.

A further advantage of using this data source is the timeframe it covers. To observe a change in pricing relationships requires a change in the competitive environment. Two major events sharpened price competition over this period. Firstly, in March 2004, Morrisons, as the fifth largest retailer, completed its acquisition of Safeway, then the fourth largest retailer, after a detailed merger investigation by the Competition Commission (2003). The effect of the merger was to consolidate the market, so the Big 5 became the Big 4. However, it also created a scramble to build market share, especially while Morrisons was busy converting Safeway stores into its own Morrisons facia, resulting in an intensification of pricing competition (Chakraborty et al. 2014). (Figure A1 in the Appendix shows how market shares of the four retailers evolved over this period, with Tesco gaining the most at the expense of Morrisons). Secondly, cost-led inflation in 2006 and through 2007-8 combined with the financial crisis 
resulted in the retailers intensifying their price promotion activity and use of price-led advertising to maintain consumer spending and store loyalty (Chakraborty et al. 2015).

Thus, over the five-year period, market-driven changes led pricing competition to become more intense, thereby presenting an opportunity for the retailers to adjust their pricing approaches towards brands and private label. In particular, with consumers becoming more price sensitive, especially over the latter half of the period, one might expect the retailers to respond by encouraging consumers to substitute brands for cheaper private label equivalents. Indeed, this fits with the observed switch marketing activity at the time (Leyland 2006; Leyland et al. 2008) and also private label capturing an increasing share of sales, which the PLMA estimated increased from 38\% to 43\% in value terms between 2004 and 2008 (see Table A3 in the Appendix for details).

In order to examine how brand and private label prices developed over the period, the price data used in this study consist of a sample of item-level weekly prices on 60 matched pairs of branded items and private label equivalents sold by all four retailers over the entire period. These 120 products (when treating each retailer's private label as the same good) represent the closest matching pairs of brand and private label equivalents taken from a constructed balanced panel dataset of just over 800 items, covering prices of all four retailers with minimal interpolation for any missing observations to generate continuous series. This in turn draws on a much larger database of over 4,000 items but for which price data were not necessarily available for all retailers or for all weeks. The main criterion used to select each pairing was that the private label item should be a direct substitute for the branded item, in terms of same/similar size/weight, format/packaging, ingredients, type/variety, as well as a "standard" private label (i.e. not designated as a "premium" or "budget" private label unless there was no obvious alternative). 
While clearly not a random or fully comprehensive sample of grocery goods, the sample of products nevertheless covers a very wide range of packaged grocery items from different product categories, with a broad mix of mass-market and more-specialist brands and their private label equivalents. The prices range from $£ 0.12$ to $£ 7.69$, with the mean being $£ 1.12$ across all 126,720 data points in the sample (i.e. the prices for 60 brands and 60 private label equivalents sold by each of four retailers over 264 weeks). The products include tinned foods, breakfast cereals, cakes, biscuits, jam, rice, flour, oils, tea, coffee, soft drinks, alcohol, pet food, and cleaning goods. Generally, there are one or two products from each category, but in some categories, notably tinned foods, breakfast cereals, table sauces and instant coffee, there is deeper category coverage with different product sizes, different quality or ingredient variants, and/or different brands. (Table A2 in the Appendix provides a full list of the items). In total, the sample of 60 matched products covers some 34 narrowly defined product categories, which vary greatly in the share of sales taken by private label, from around two-thirds for cooking oils down to less than a tenth for toothpaste. (Table A3 in the Appendix shows total volume and value private label shares for each of the 34 narrow product categories over the period).

The effects of the Morrisons/Safeway merger emerge as a distinct feature in the observed pricing patterns. In respect of the prices reported for Morrisons, for the first nine months these were prices collected from Safeway stores, independently operated until the conclusion of the merger on 8 March 2004. Thus, from week 1 (10 November 2003) to week 19 (7 March 2004), prices are for Safeway as an independent retailer, then from week 20 to week 41 (16 August 2004), the reported prices are for Safeway under the ownership and control of Morrisons, and from week 42 (23 August 2004) onwards, the reported prices are for Morrisons own stores. In line with Chakraborty et al. $(2014 ; 2015)$, we will see that the merger had an immediate and far-reaching impact on pricing behaviour, not just on Morrisons/Safeway, but for the other three retailers as well. 


\section{Pricing patterns}

Perhaps not surprisingly given the array of product categories covered and the very different nature of the brands in respect of their sizes, market share, penetration level, and extent of consumer loyalty, there is significant variation in the observed pricing patterns across the matched pairs. The purpose of this section is to summarise the general trends that emerge and consider whether they might be indicative of the strategic pricing behaviour discussed in section 3 above.

First, though, from a casual inspection of the price patterns for all 60 matched pairings, it was evident that a number of the pairings appeared to fit quite closely the four pricing tactics shown in Figures 1. For illustration, Figures 2-5 each show a matched pair that appears to fit closely each of the four pricing tactics. In each case, the four different coloured solid lines show the brand price for the four retailers, while the four dashed lines correspond to the private label price for the same four retailers.

The pricing pattern shown in Figure 2 is not untypical in the sense of the high frequency of temporary price reductions (TPRs) applied to the brand (often as half price offers, or as here for a straight £1), compared to the much steadier prices on private label. Thus even though the trend on the brand's regular price might be upwards, many consumers will likely be buying the brand on discount price promotions (not least on storable ambient groceries for which the consumer can stock up), thus bringing down the average price paid.

In Figure 3, there is again an increase in the regular price of the brand over time, but interspersed with price promotions especially towards the end of the period. In contrast, though, the private label prices falls quite markedly over time, so expanding the brand/privatelabel price gap very considerably. In these cases, the falling price of the private label equivalent may be indicative of reduced product quality or the retailer repositioning the standard private label in the category pricing architecture (e.g. taking a lower margin on private label). 
Figure 2. Example of Rising Brand Prices

KELLOGGS CORN FLAKES 500G

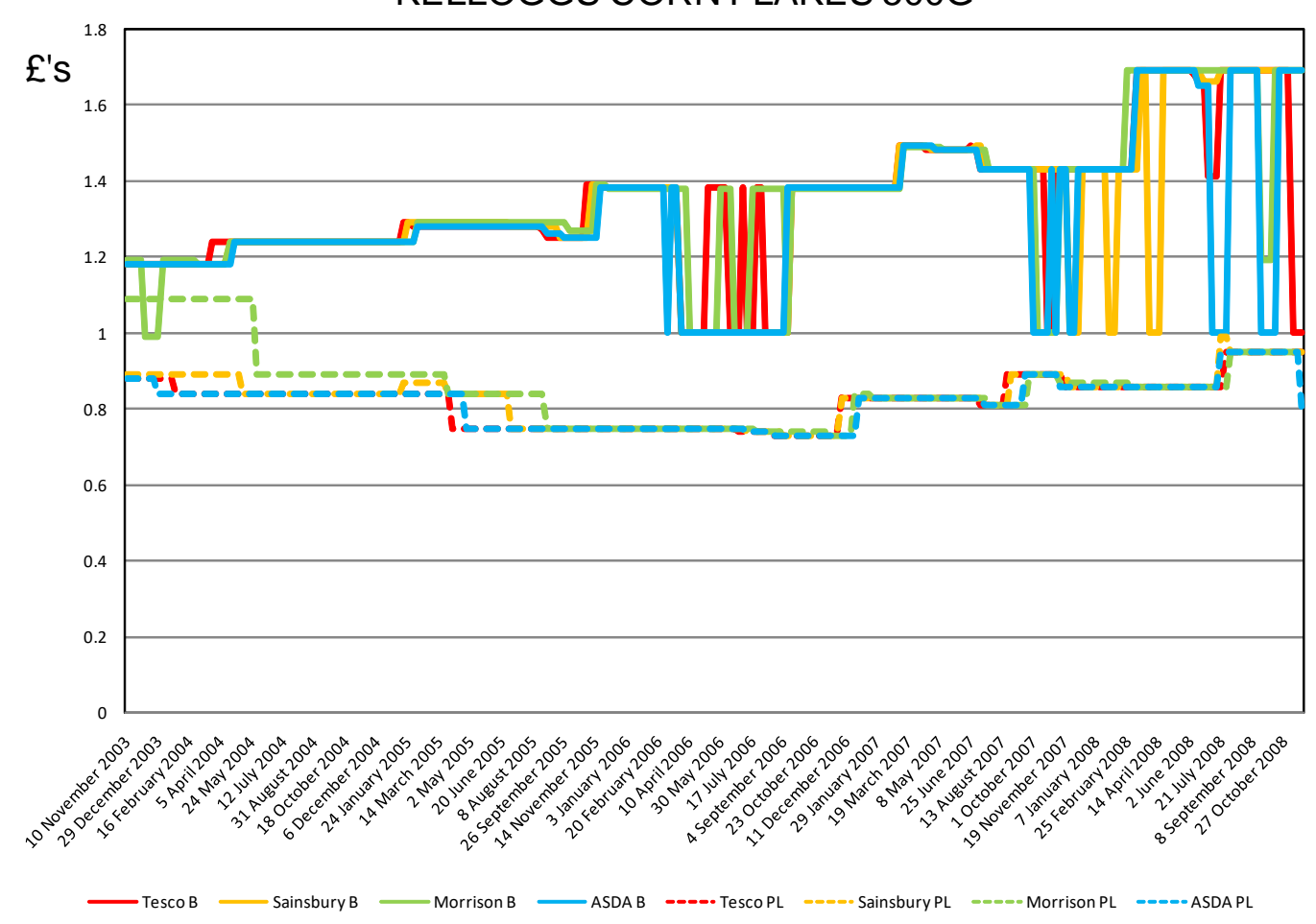

Figure 3. Example of Falling Private Label Prices

NESCAFE INSTANT COFFEE 200G

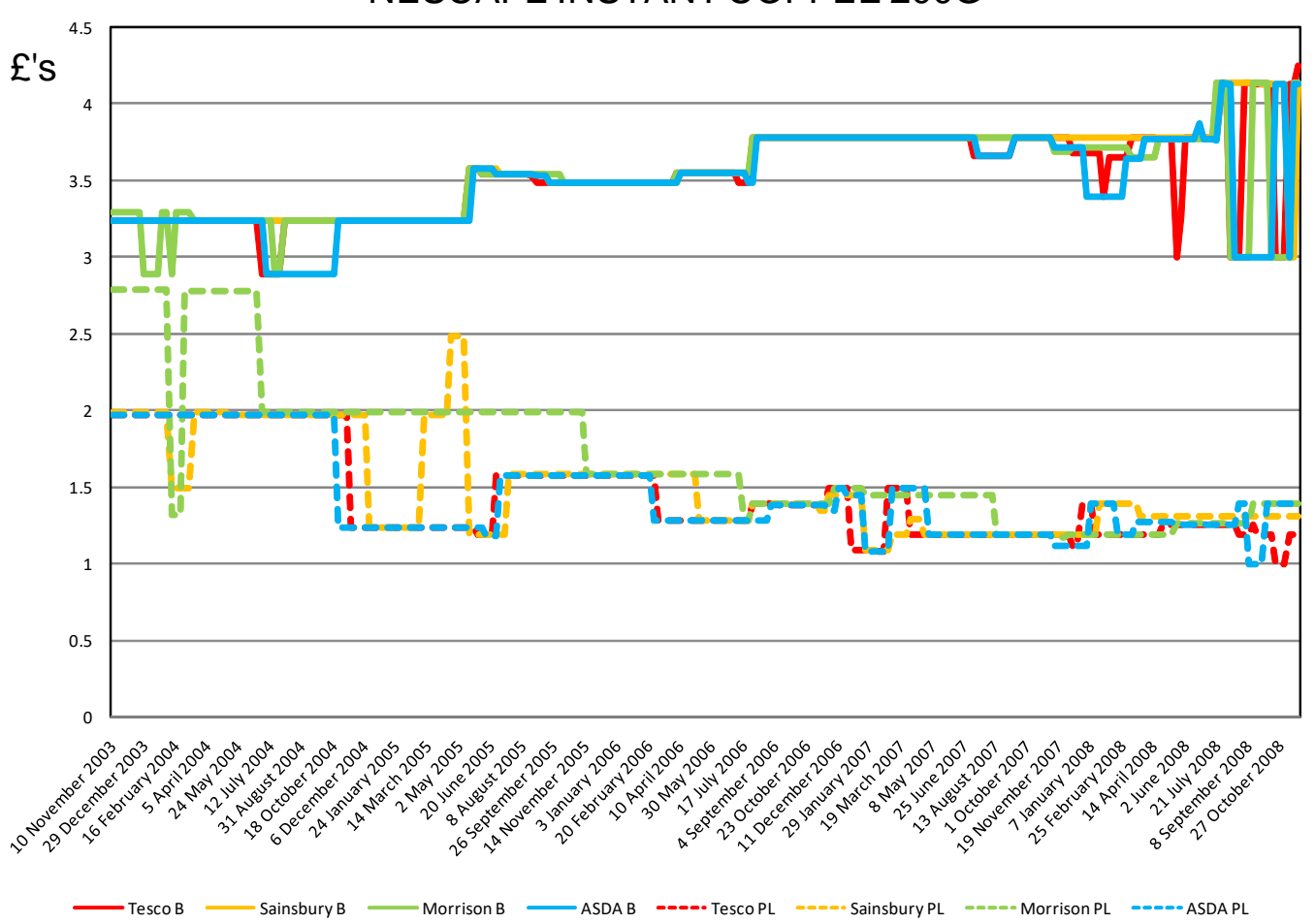


Figure 4. Example of Private Label Prices Tracking Brand Prices FLORA PURE SUNFLOWER OIL 1LT BOTTLE

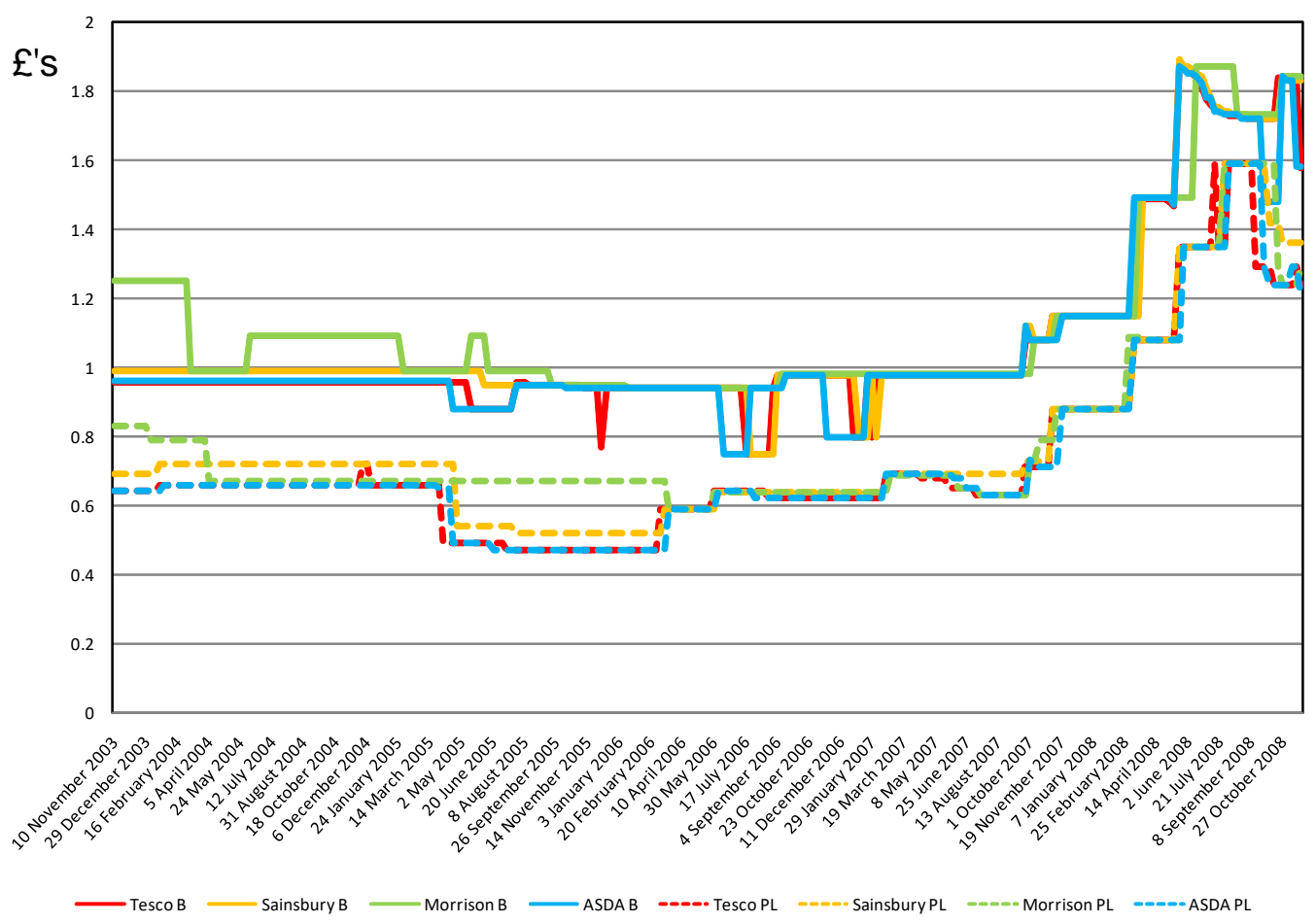

Figure 5. Example of Time-Varying Brand Prices

ST IVEL UTTERLY BUTTERLY 500G

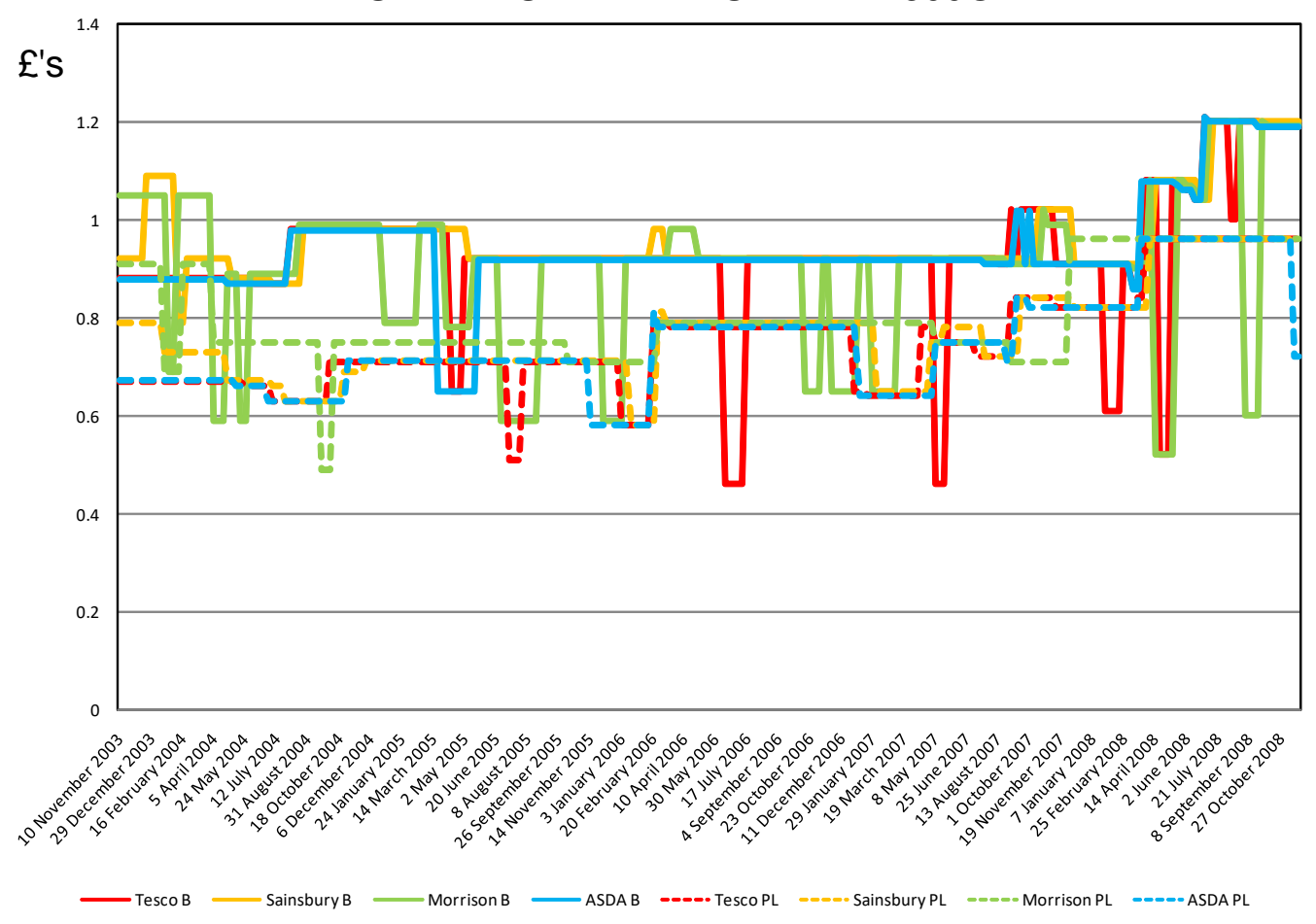


Figure 4 shows a case where the prices on the brand and private label equivalent closely track each other over time. In this particular instance, the sharp price increases in 2007-8 coincided with sharply increasing global supply prices for the commodity concerned (sunflower oil) and a similar pattern occurred on other commodity products as well during this inflationary period. In these cases, parallel pricing for brands and private labels were essentially a feature of changing supply/wholesale prices and applied equally across retailers.

In Figure 5, the brand operates with so many temporary price reductions that often its price is below the private label equivalent, while at other times when it is not on special offer then its price is significantly higher. This price volatility increases over time, while the price gap narrows on regular prices between the brand and the private label equivalent. With prices on the brand changing so frequently with so many price promotions, the meaning of a "regular" price becomes less clear, and consumers may be inclined to wait for price promotions on the brand and perhaps experiment with buying private label when the brand price is high and the price gap with private label is wide.

Other cases demonstrated similar patterns to those shown in Figures 2-5, but there were also more mixed patterns where price trends for brands and private label were variable.

These individual patterns are interesting but, of course, at best only provide circumstantial support for the presence of strategic pricing, since each of them could quite easily have a more innocent explanation for the observed pattern, e.g. due to a change in the demand or cost position of the individual products. Accordingly, to move beyond the individual product level, that might simply represent a spurious or one-off association, the rest of this section examines price trends for the sample as a whole to see whether any dominant patterns of pricing behaviour emerge.

The sample-level analysis that follows centres on four key features of the pricing of brands and private label equivalents with the following key results to emerge: 
1. Price correlation - prices on matching brands and private labels are moderately correlated within each retailer, but brand prices are strongly correlated across competing retailers, and so too are private label prices, indicating a retail focus on itemby-item prices across rivals

2. Price gap - the price gap between brands and private labels increases on average over time on regular prices, but there is an increasing tendency for brands to be used for deep short-run price promotions (typically "half price” or “£1” special offers)

3. Price matching - price matching across all four retailers on an item-by-item basis becomes an increasingly strong feature until mid-2007, after which it becomes less common as price dispersion increased during an inflationary period in 2008

4. Price volatility - brand prices are much more variable than private label prices both in terms of small and large price changes

\subsection{Intra-retailer and inter-retailer price correlations}

Usually when goods are clear substitutes they will share common price movements in response to demand and cost changes, so over time their prices should follow each other quite closely and tend to be highly correlated. Table 3 reports the sample average correlation coefficients for products prices in respect of intra-retailer correlation between the brands (designated by "B") and their private label equivalents (designated by "OL" for "own label") as well as across inter-retailer correlations (between Tesco, Sainsbury, Morrisons, and Asda). ${ }^{5}$ As a precaution, and in line with Lan and Dobson (2017) analysing the intensity of grocery

\footnotetext{
${ }^{5}$ The correlation coefficient between two price series $\mathrm{X}$ and $\mathrm{Y}$ is $\rho_{X, Y}=\operatorname{cov}(X, Y) /\left(\sigma_{X} \sigma_{Y}\right)$, where $\operatorname{cov}(X, Y)$ is the covariance of $\mathrm{X}$ and $\mathrm{Y}, \sigma_{X}$ is the standard deviation of $\mathrm{X}$, and $\sigma_{Y}$ is the standard deviation of $\mathrm{Y}$. The reported values in Table 1 are for the average correlation coefficient values for the 60 corresponding products.
} 
price competition, the discussion of the results in the table focuses on relative values rather than absolute values in case there are spurious correlation issues affecting the levels. ${ }^{6}$

Table 3. Price Correlation Analysis - Average Correlation Coefficients across Sample

\begin{tabular}{|r|c|c|c|c|c|c|c|c|}
\hline & Tesco B & Sains B & Morr B & ASDA B & Tesco OL & Sains OL & Morr OL & ASDA OL \\
\hline Tesco B & 1.000 & 0.628 & 0.503 & 0.682 & 0.180 & 0.132 & 0.075 & 0.192 \\
\hline Sains B & 0.628 & 1.000 & 0.523 & 0.620 & 0.227 & 0.217 & 0.129 & 0.250 \\
\hline Morr B & 0.503 & 0.523 & 1.000 & 0.503 & 0.220 & 0.235 & 0.232 & 0.239 \\
\hline ASDA B & 0.682 & 0.620 & 0.503 & 1.000 & 0.183 & 0.154 & 0.083 & 0.212 \\
\hline Tesco OL & 0.180 & 0.227 & 0.220 & 0.183 & 1.000 & 0.652 & 0.505 & 0.830 \\
\hline Sains OL & 0.132 & 0.217 & 0.235 & 0.154 & 0.652 & 1.000 & 0.583 & 0.622 \\
\hline Morr OL & 0.075 & 0.129 & 0.232 & 0.083 & 0.505 & 0.583 & 1.000 & 0.493 \\
\hline ASDA OL & 0.192 & 0.250 & 0.239 & 0.212 & 0.830 & 0.622 & 0.493 & 1.000 \\
\hline
\end{tabular}

The striking result is that brand and private label prices seem to be only moderately correlated within each retailer but more strongly correlated for the same/equivalent product sold across the retailers; i.e. intra-retailer brand/private-label correlation is positive but moderate, while inter-retailer item-by-item correlation is positive and relatively strong. The first finding runs counter to the notion of umbrella pricing being dominant, where private label prices shield under brand prices and move in step with each other. In contrast, the second finding shows that the prices for the same brand across the retailers are more strongly correlated and equally prices for the same private label across the retailers are more strongly correlated. This suggests, as discussed above in section 3, that retailers are keen to maintain their prices in line with each other on an item-by-item basis and if strategic pricing is going on at the product category level, then all four retailers are likely to be employing the same tactic.

The moderate correlation on brand and private label prices should not come as a surprise if the retailers are using these products to target different consumers as part of their category

\footnotetext{
6 In particular, the infrequent price changes with weekly data and the possibility of non-stationarity and cointegration issues could affect the correlation values (Bishop and Walker 2010, chapter 10).
} 
pricing strategy for devising pricing architectures intended to segment and better target consumers by their price/quality preferences. For example, the retailers could be pricing brands higher to target brand-seeking consumers and private label lower to target value-seeking consumers (i.e. in line with Soberman and Parker 2006; Gabrielsen and Sørgard 2007, Perloff et al. 2012; Dobson and Chakraborty 2014). In this case, consumers may view the products as substitutable, to a greater or lesser degree depending on their individual preferences. However, the retailers' perspective could be that the brand and private label pair are complementary in the sense that they represent a combination designed to appeal to the widest possible consumer base. Thus, the modest correlation does not mean that the products are not in direct or even intense competition with each other, only that the retailer adjusts prices in a manner to manage category sales while being highly responsive to rival retailers' prices on an item-by-item basis.

\subsection{Brand-PL price gap}

Measuring the brand premium as (brand price - PL price)/(PL price) expressed as a percentage and averaged over the 60 items, Figure 6 shows that the price gap between each brand and private label pair has on average increased substantially, up by $45 \%$. This widening price gap is consistent with both the "rip-off brand" tactic and the "private label value champion" tactic.

Figure 7 shows the mean brand and private label prices for the sample, which lends some qualified support to both tactics, indicating that retailers have pushed up brand prices on average over time, while pushing down private label prices. The figure also shows the immediate impact that Morrisons made on acquiring Safeway, lowering both its brand and private label prices as soon as the merger was completed, which in turn seems to have spurred Sainsbury to lower its prices. However, throughout the five-year period we can observe that Tesco and Asda maintained slightly lower private label prices on average than Morrisons and Sainsbury's, while average brand prices amongst the four retailers appear closer. 
Figure 6. Mean Brand-Private Label Price Gap (\%)

Brand Premium (\%) By Retailer

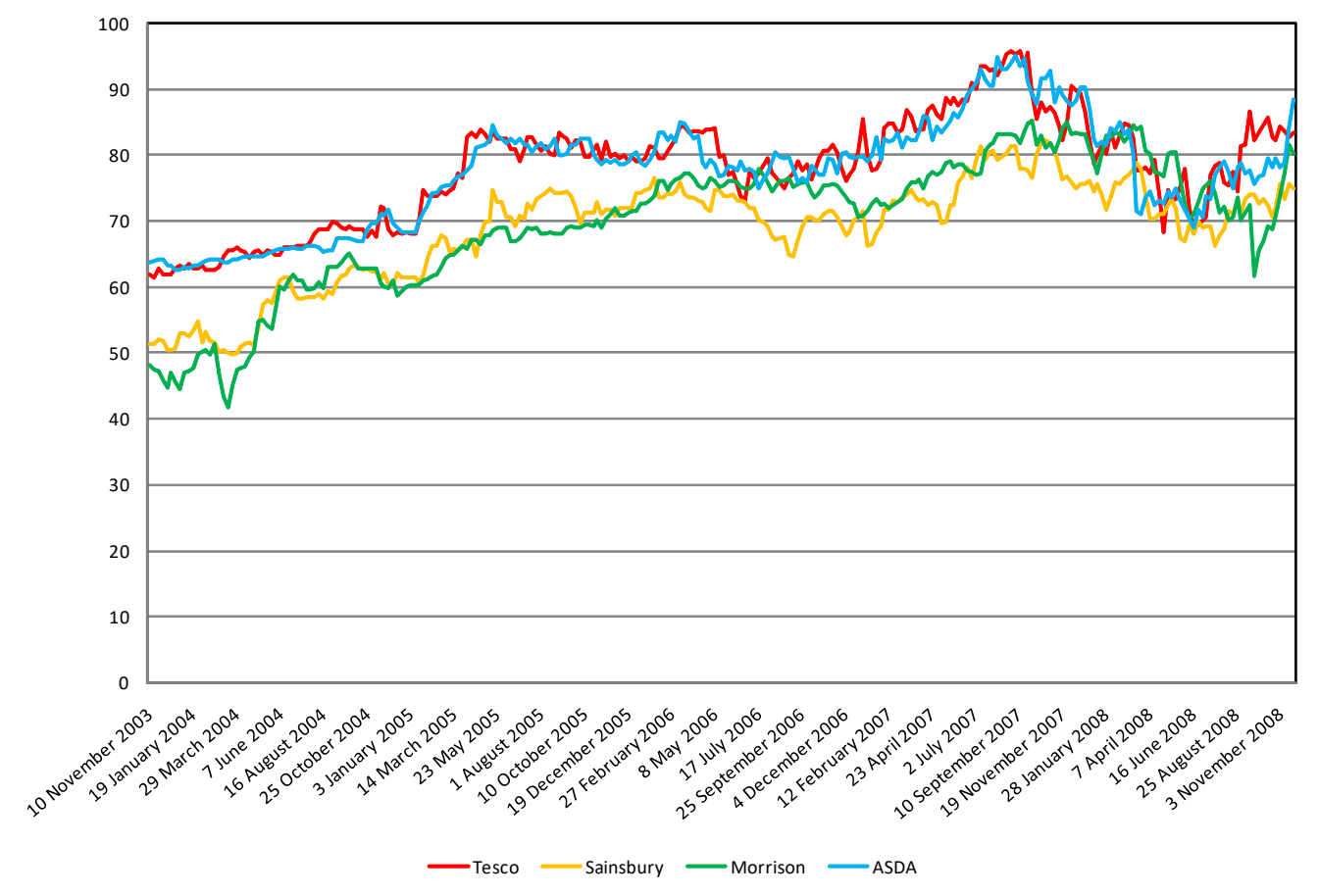

Figure 7. Sample Mean Values of Brand and Private Label Prices Mean Brand \& PL Prices by Retailer (£'s)

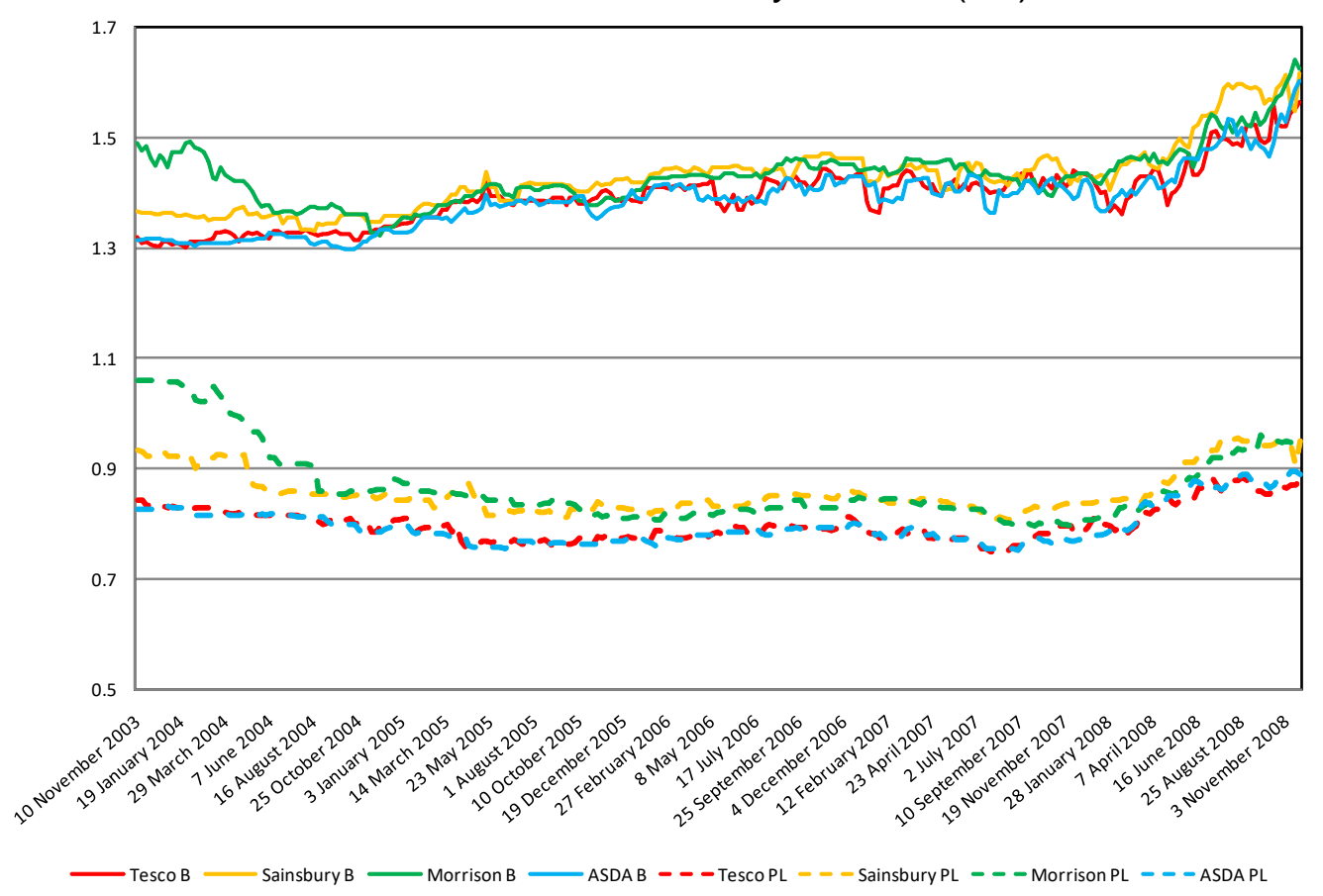




\subsection{Inter-retailer price dispersion and price matching}

To consider more formally the extent of price differences across the four retailers, Figure 8 shows the weekly average coefficient of variation (as the ratio of the standard deviation to the mean of the retailers' prices) respectively for the 60 brands and 60 private labels. Following the Morrisons/Safeway merger, price differences considerably narrowed on both brands and private labels, with the former displaying less price dispersion until 2008, when price dispersion across the retailers increased for both product types, but especially for brands.

Figure 8. Price Dispersion across Retailers

Mean Coefficient of Variation for Brands and PL

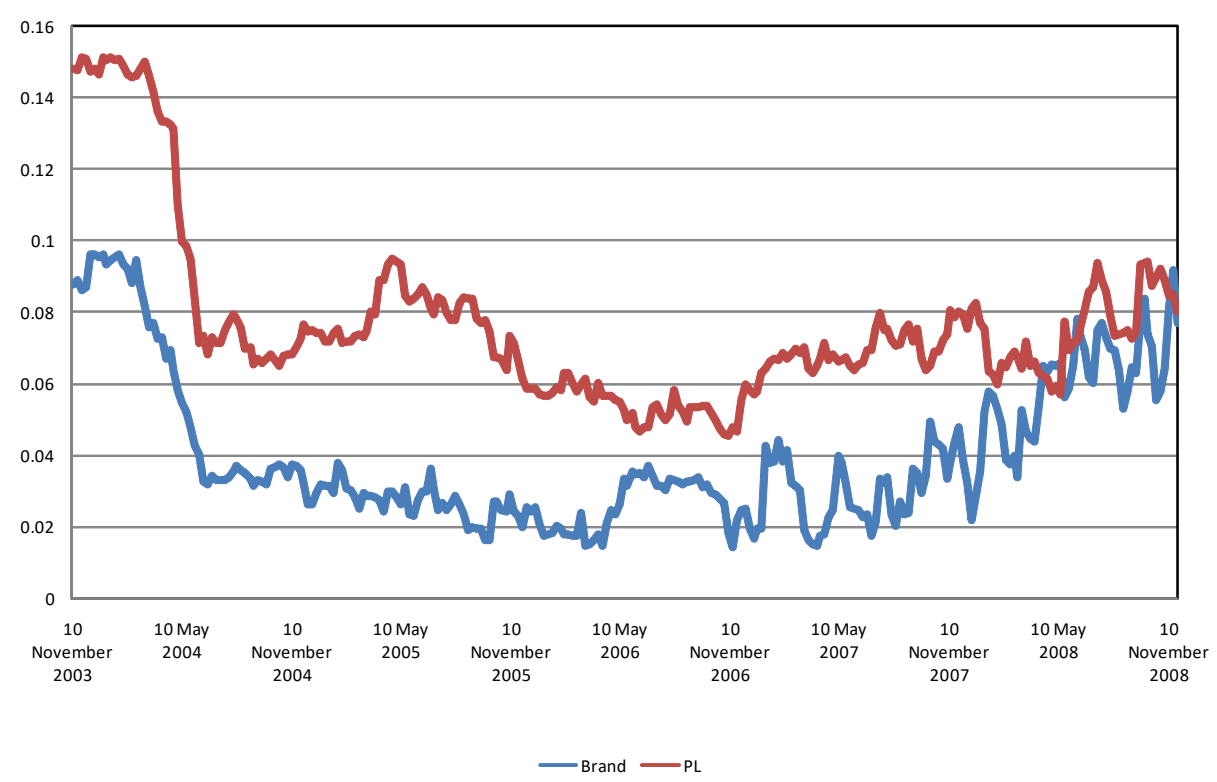

In respect of the extent of exact price matching across the retailers, Figures 9 and 10 show the percentage of products with exact matching. The mid-blue area refers to " 4 of a kind", as the percentage of products in a given week where all four retailers set the same price. The red area relates to "3 of a kind", where three of the four retailers set the same price. The green area is for those products where there are " 2 pairs", where one pair of retailers set one price and another pair set a different common price. The purple area is the case of " 1 pair", where one pair of retailers sets one price and the other two set two different prices. The light-blue area is for products where there are "no pairs", where all four retailers set different prices. 
Figure 9. Exact Price Matching on Brands by Retailer Combinations

Retailer Price Matching on Brands

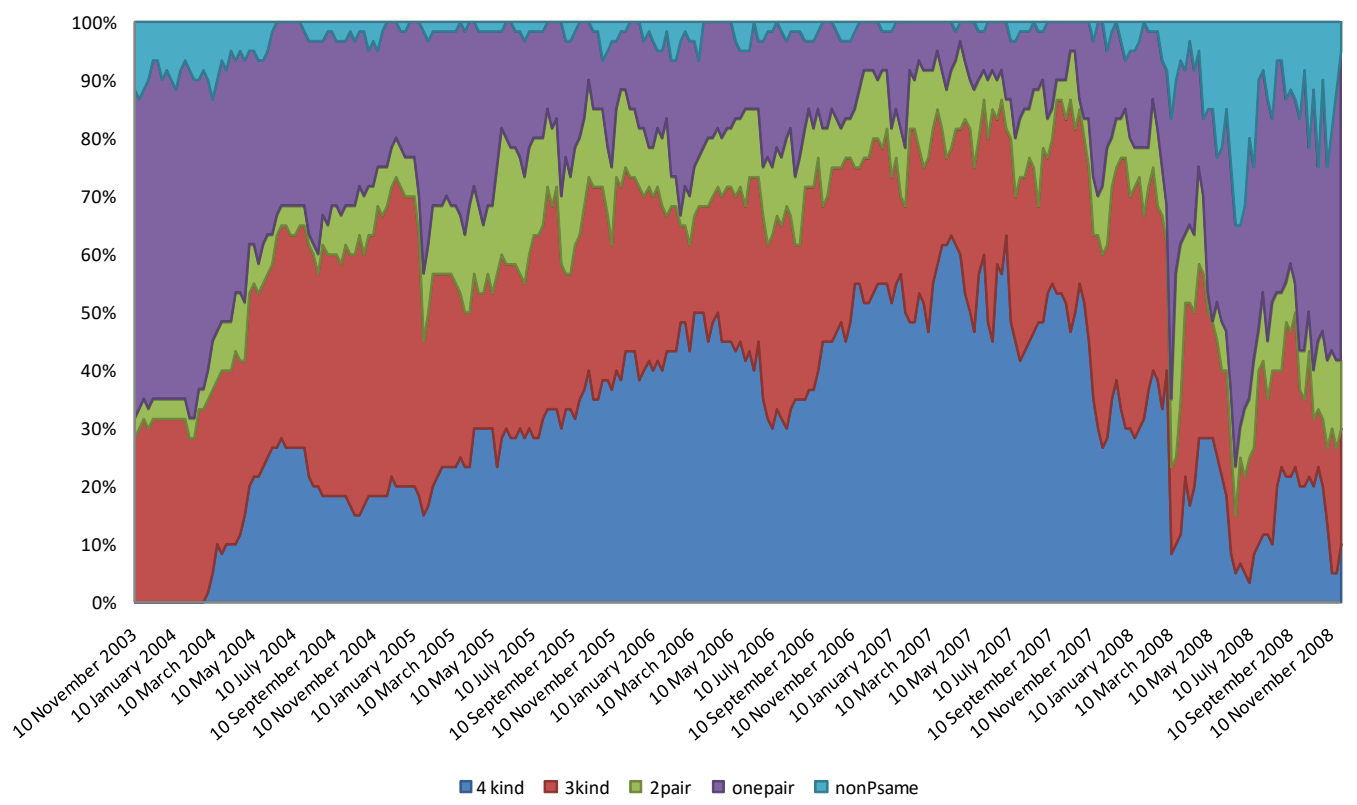

Figure 10. Exact Price Matching on Private Label by Retailer Combinations

Retailer Price Matching on Private Label

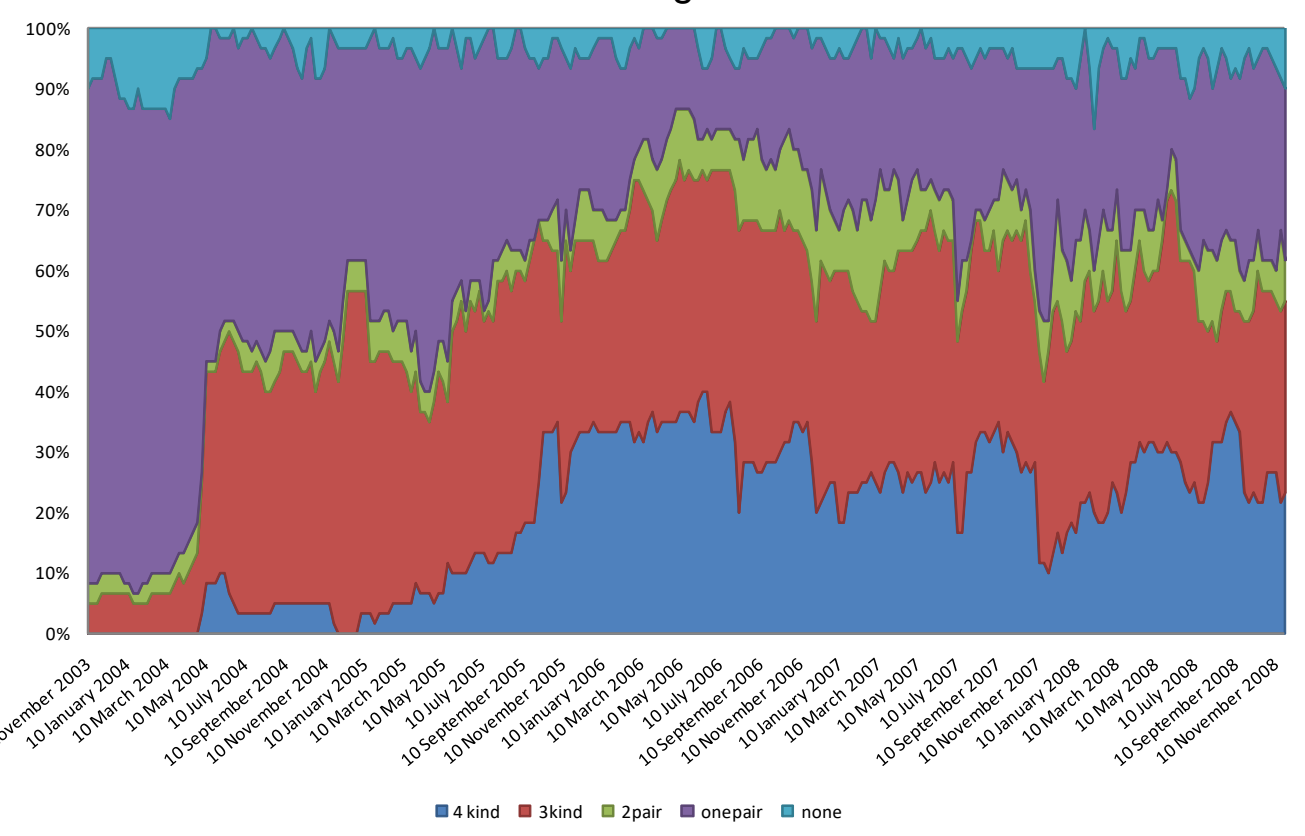


The two figures shows that at the beginning of the five-year period there was very little price matching, but in the wake of the Morrisons/Safeway merger exact price matching became much more common for both brands and private label, peaking in 2006/7, before falling away in 2008 as the financial crisis deepened. Taking the period as a whole, this extent of price matching highlights the very strong interdependent nature of retail price competition amongst these four retailers.

\subsection{Brand and private label price volatility}

A clear indication why price matching might have broken down in 2008 comes from Figure 11, which shows the number of price cuts and price rises as a three-month moving average (to smooth out the week-by-week differences). Prices are much more volatile towards the end of the period, which coincides with inflation in global commodity prices and the financial crisis (Chakraborty et al. 2015). The upshot is that average retail prices increased sharply, as Figure 7 showed. However, the indication given by Figure 11 in respect of the number of price cuts and price rises is that there were far more price cuts during this period, reaching a point in mid-2008 with nearly half of all brand prices cut in a single week.

So how can these seemingly contradictory findings be reconciled? The answer lies in the size of the price cuts. As Figure 12 shows, the retailers were heavily engaged in cutting prices by a single penny. However, as the figure also shows, most single penny price cutting applied to brands and not to private label. Thus, as inflation and the economic crisis deepened, the retailers responded by adjusting mostly brand prices, either making tiny price cuts of a penny at a time or running with larger promotional discounts while at the same time increasing the prices on other brands. The net effect was increasing average prices, as Figure 7 shows, but the very high volume of price cuts and discounts appear the retailers attempting to signal to consumers that they were trying to price as competitively possible despite the inflation. 
Figure 11. Price Volatility

Number of Price Cuts \& Rises Per Week (3mth MA)

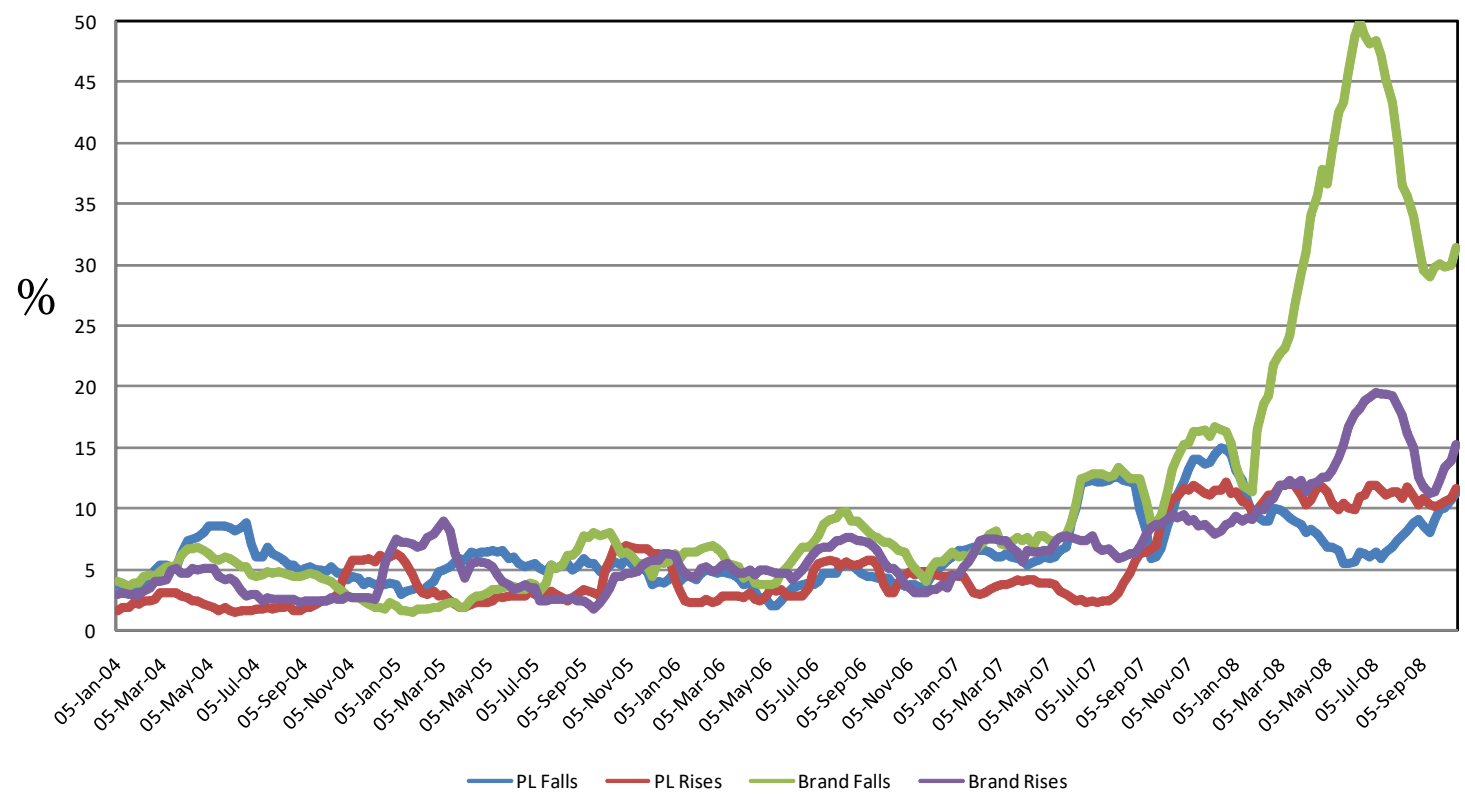

Figure 12. Single Penny Price Cuts

Number of $1 p$ Price Cuts each Week for Brands \& PL

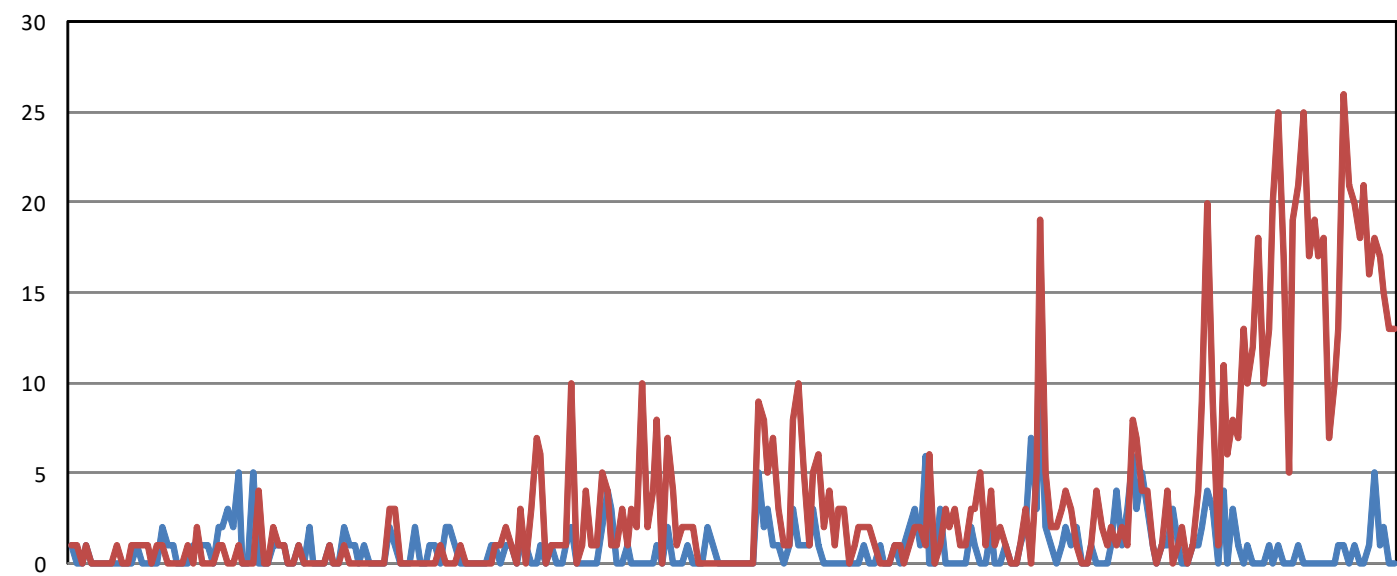

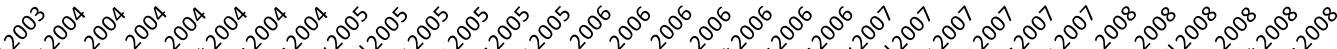
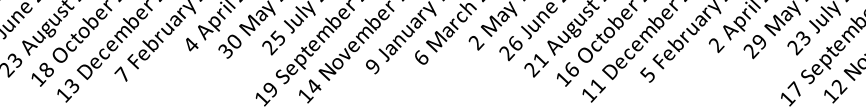

$$
\longrightarrow \mathrm{PL} \longrightarrow \text { Brand }
$$


Across the whole five-year period, it is clear that the number and size of price changes were fundamentally different for the brands compared to their private label equivalents. Figure 13 shows the cumulative frequency for $1 \mathrm{p}$ through to $30 \mathrm{p}$ price changes for brands and private labels, with price cuts shown on the left side and price rises shown on the right side. The figure reveals that there were far more price cuts on brands than on private labels, but a large portion of these brand price changes were very small, typically between $1 p$ and $4 p$. Conversely, the price increases on brands tend to be larger than on private label.

Figure 13. Cumulative Frequency of Brand and Private Label Price Movements Brand \& PL Price Changes:

\section{Cumulative Distribution (1p-30p)}

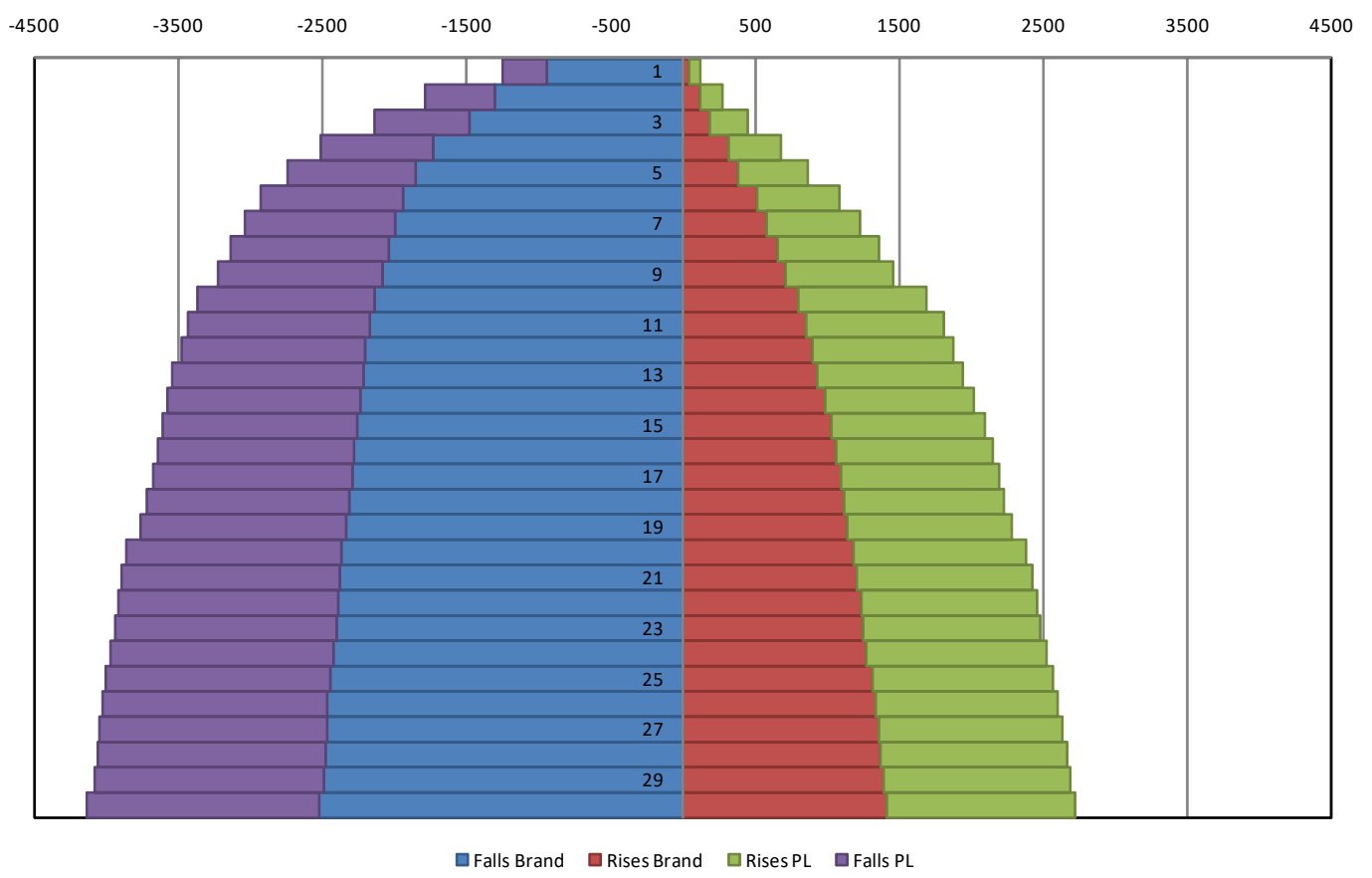

Figures 14 and 15, respectively for brands and private labels, break down the cumulative frequency of price changes for $1 \mathrm{p}$ through to $30 \mathrm{p}$ by each of the four retailers. Figure 14 shows that Tesco and Asda made the majority of the small price changes on brands. In contrast, from Figure 15, it is clear that the retailers changed the private label prices less frequently and there was less of a difference across the retailers in the scale of these price changes. 
Figure 14. Price Brand Churn across Retailers - Cumulative Frequency

Brand Price Changes:

Cumulative Distribution by Retailer (1p-30p)

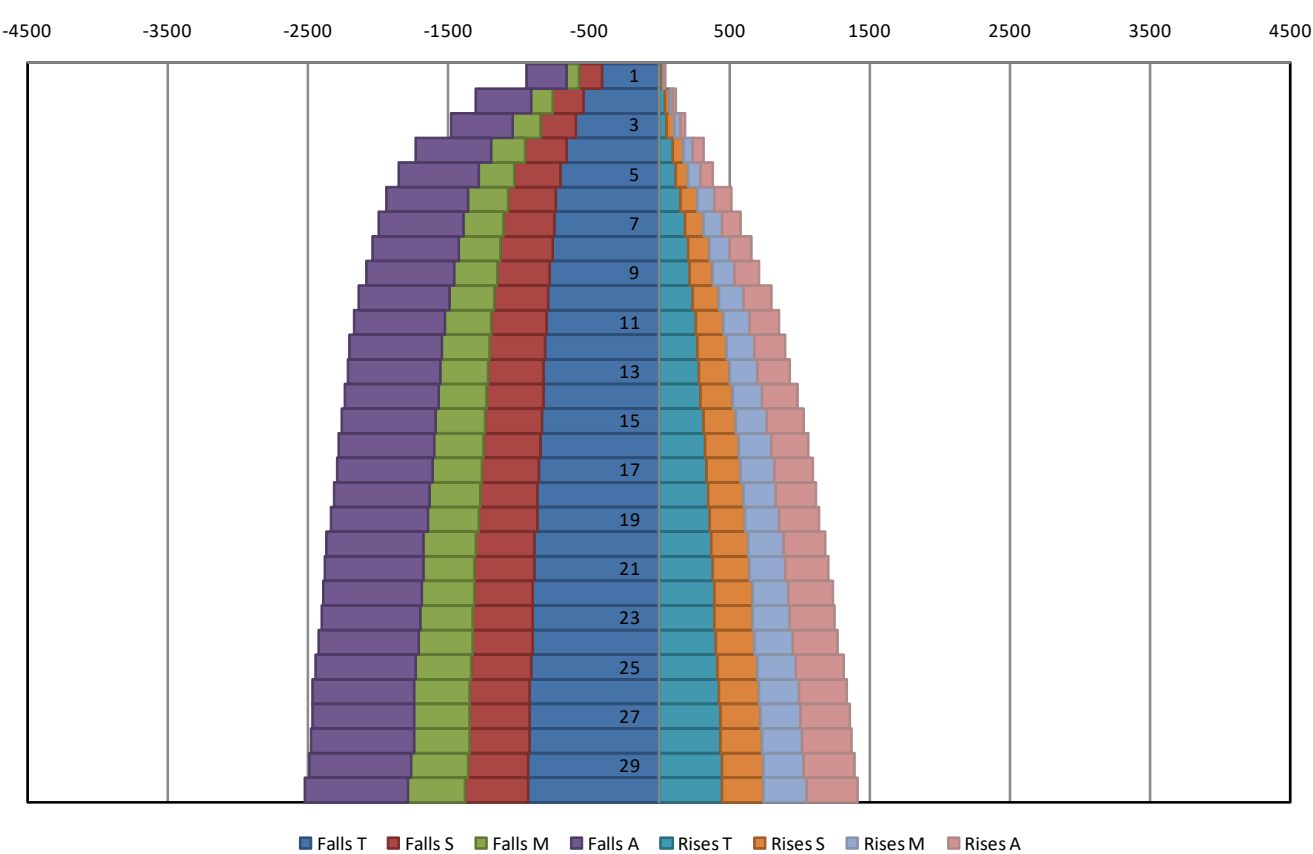

Figure 15. Private Label Price Churn across Retailers - Cumulative Frequency PL Price Changes:

Cumulative Distribution by Retailer (1p-30p)

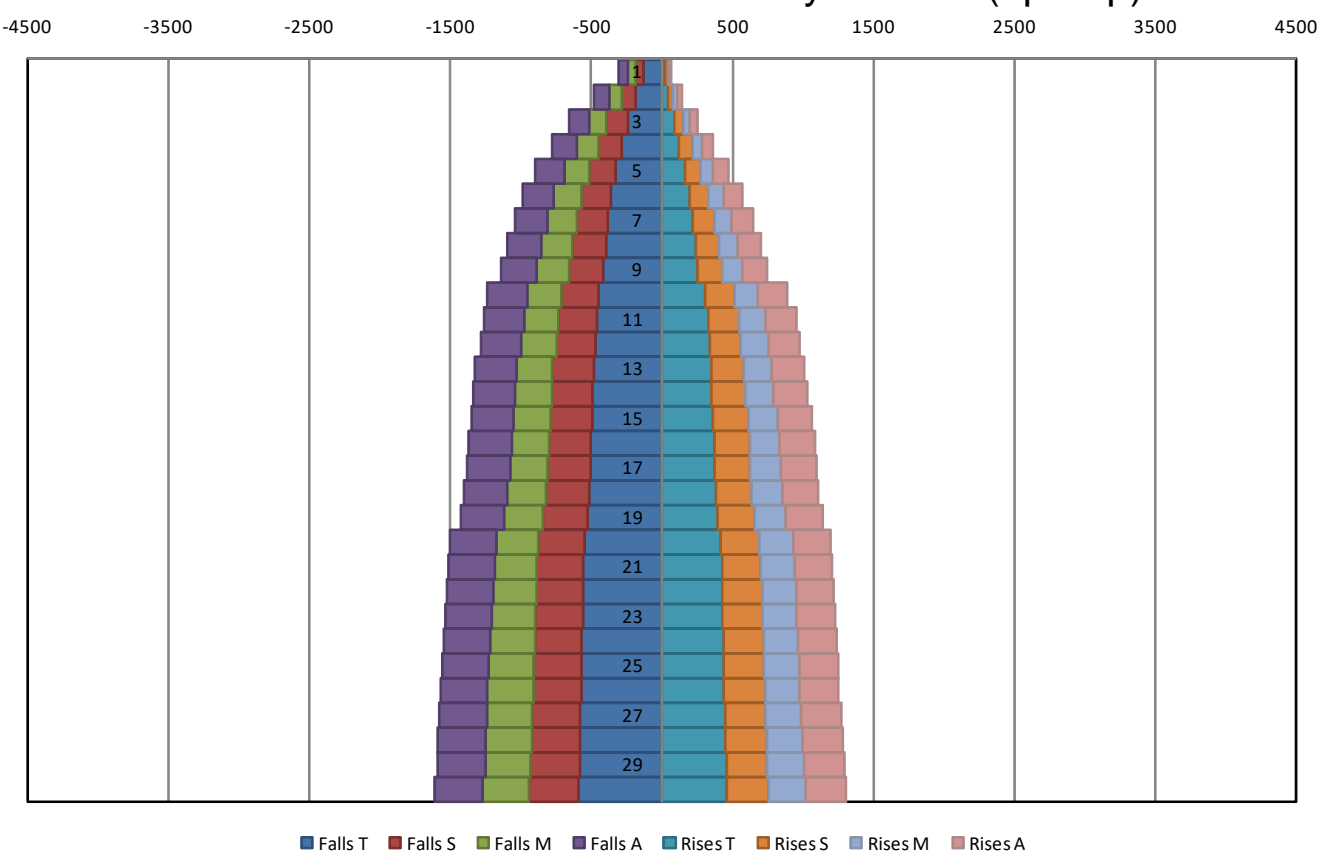


The greater price volatility on brands than on private label is consistent with the "dubious brand value" tactic. However, this might also be a symptom of retailers seeking to make flattering price comparisons over rivals in terms of who offers the greatest number of lower prices than its rivals, as evident from the price comparison advertising and publicity campaigns used by the retailers over this period (Chakraborty et al. 2015).

\section{Conclusion}

This study demonstrates that a change in the competitive environment can trigger a distinct change in the pricing applied to brands and private labels. Whether by deliberate design or an unintended outcome of competitive pricing, the treatment brands receive could adversely affect their immediate or longer-term market share and profitability. Hiking the brand premium (here by an average of $45 \%$ ) will inevitably make private label goods appear to offer better value. Operating high frequency deep discount promotions will compensate by boosting brand sales in the short term but could undermine longer-term brand loyalty and lower consumers' reference prices, which may boost profits for retailers but not for brand producers (Ball 2009b).

The options for brand producers in responding to strategic pricing by retailers look to be limited. As with trying to defend against other forms of switch marketing, threats to withhold supplies or reduce promotional support do not look credible in this environment even for strong brand owners. Instead, the best prospects for brand owners lie in innovating, improving product quality and advertising to distinguish their brands from private label imitations and maintain consumer loyalty so they remain distinct must-stock products (Kumar and Steenkamp 2007).

Should switch marketing and retailer strategic pricing matter to consumers? Perhaps not if product choice is wide and prices represent good value. However, consumer detriment could arise. Firstly, using umbrella pricing with private label simply tracking brand prices and not following costs is likely to lead to poor value for consumers (Competition Commission 2000). Secondly, intentionally spreading the price gap to distort pricing architectures may mislead 
consumers (through their price-quality associations) as to the value actually on offer. Thirdly, the effect of incessant yo-yo pricing by repeatedly changing the brand price up and down may reduce its perceived value. Fourthly, pushing up brand prices to divert sales towards private label might end up resulting in brand withdrawal and so eventually reduced choice. Fifthly, product quality may decline over the longer term when the moral hazard problem from retailers exploiting their double agent position deters future brand investment by brand owners.

The retailer's chief objective in using strategic pricing as switch marketing appears to be less about displacing brands and more about segmenting consumers. As a form of self-selection (second-degree) price discrimination, this can be economically benign when it enhances product choice and generates additional sales. However, as Dobson and Chakraborty (2014) demonstrate in a range of contexts, this can be detrimental when it raises average prices by hiking brand prices to exploit brand loyal consumers while driving value-conscious consumers to buy cheaper private label. The policy remedy could be to give brand producers greater control over the retail prices of their goods, such as being permitted to use maximum resale price maintenance as a way of constraining what retailers can charge for brands. Olbrich and Burr (2005) go further and argue for relaxing the prohibition on fixed resale price maintenance to allow brand owners to fix resale prices as a means to stop retailers using excessive and artificial high-low pricing on brands.

Future research might wish to extend the scope of the present study beyond utilising price data. In particular, access to both price and sales data could allow for studying the effectiveness of the different pricing tactics outlined in this paper in favouring private label sales and the consequences for brand sales. Similarly, extending the study period or considering a different timeframe or another country could provide fresh insights about how retailers price brands and private labels in different market conditions and competitive circumstances. Such research would be very timely in view of the seemingly inexorable global growth of private label. 


\section{APPENDIX - Further information on the market and product sample}

Table A1. Sales Performance of Top 4 UK Grocery Retailers, 2008

\begin{tabular}{|l|c|c|c|c|}
\hline \multicolumn{1}{|c|}{ Measure } & Tesco & Asda & Sainsbury's & Morrisons \\
\hline Share of trade (\%) & 28.1 & 15.5 & 14.3 & 10.4 \\
\hline Penetration - all shoppers (\%) & 84.9 & 67.9 & 63.7 & 60.2 \\
\hline Average visits per shopper p.a. & 39.9 & 25.7 & 27.5 & 24.6 \\
\hline Average spend per shopper (£) & 1265.74 & 871.83 & 862.18 & 606.05 \\
\hline Average spend per visit (£m) & 31.75 & 33.95 & 31.34 & 26.85 \\
\hline Penetration - main shoppers (\%) & 34 & 18 & 16 & 13 \\
\hline Retailer loyalty - main shoppers (\%) & 65 & 64 & 66 & 60 \\
\hline \% Spend on promotional offer & 28 & 28 & 30 & 30 \\
\hline Own label share (\%) & 47 & 47 & 48 & 47 \\
\hline
\end{tabular}

Source: Adapted from Nielsen (2009)

Figure A1. Market Share Trends of Top 4 UK Grocery Retailers, 2003-2008

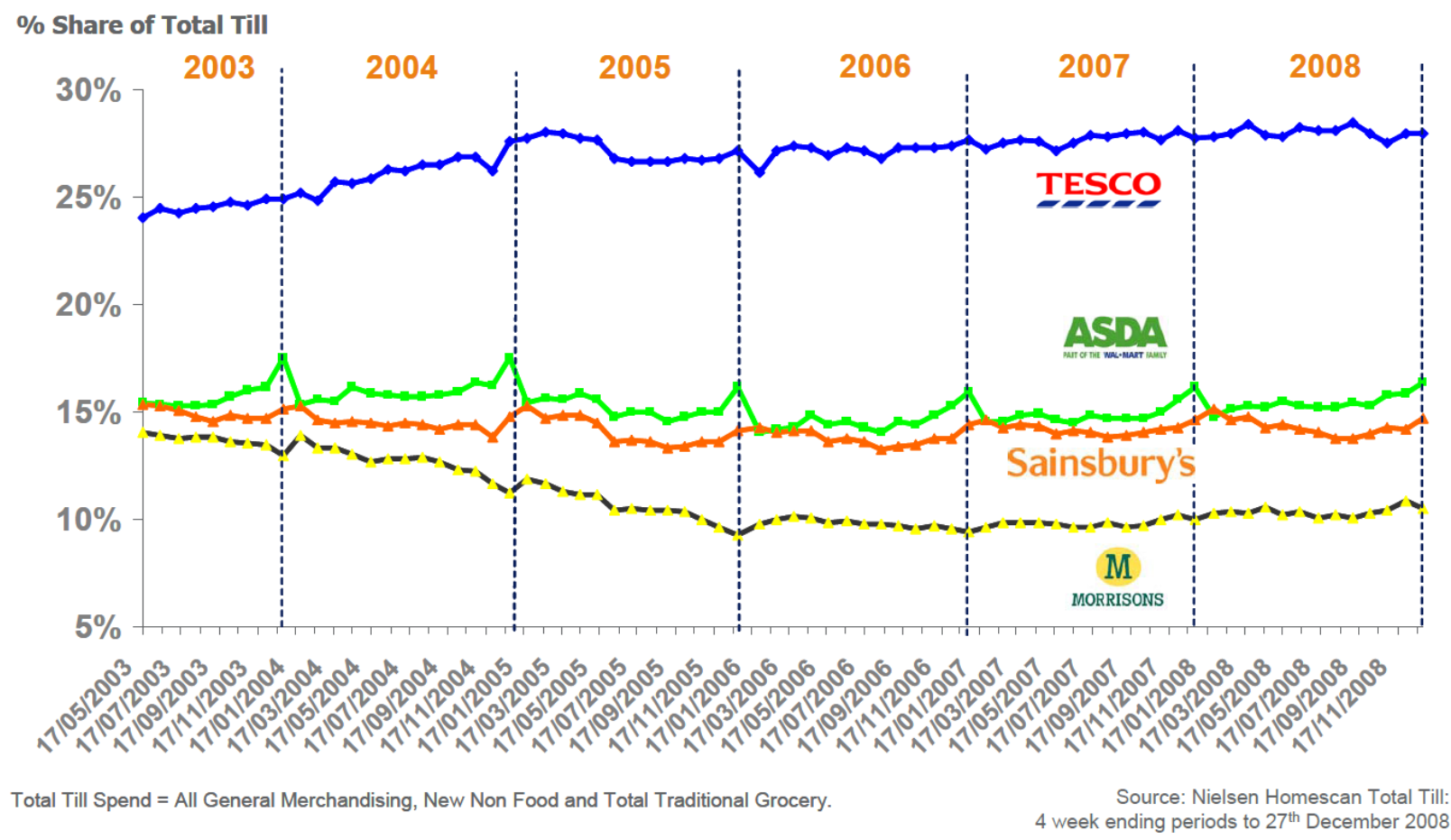

Source: Nielsen (2009) 
Table A2. List of products in the matched-pairs sample

\begin{tabular}{|c|c|}
\hline BRAND ITEM & PRIVATE (OWN) LABEL ITEM \\
\hline MR KIPLING BRAMLEY APPLE PIES X6 & OL BRAMLEY APPLE PIES 6 PACK \\
\hline MR KIPLING CHERRY BAKEWELLS 5/6 PACK & OL CHERRY BAKEWELL TARTS 6 PACK \\
\hline HEINZ BAKED BEANS 415G/420G & OL BAKED BEANS IN TOMATO SAUCE 420G-439G \\
\hline HEINZ BAKED BEANS IN TOMATO SCE 200G/205G & OL BAKED BEANS IN TOMATO SAUCE 220G \\
\hline HEINZ BAKED BEANS \& 4 PORK SAUSAGES 200G/205G & OL BAKED BEANS \& 4 PORK SAUSAGES 200G/220G \\
\hline HEINZ BAKED BEANS \& PORK SAUSAGES 8'S 420G & OL BAKED BEANS \& 8 PORK SAUSAGES 420G CAN \\
\hline HEINZ WEIGHT WATCHERS BAKED BEANS 420G & OL H/E BAKED BEANS LESS SUGAR/SALT 420G \\
\hline HEINZ RAVIOLI IN TOMATO SAUCE 200G CAN & OL RAVIOLI IN TOMATO SCE 400G CAN \\
\hline HEINZ SPAGHETTI BOLOGNESE 400G/405G CAN & OL SPAGHETTI BOLOGNESE 410G CAN \\
\hline HEINZ SPAGHETTI IN TOMATO SAUCE 400G & OL SPAGHETTI IN TOMATO SAUCE ANY 410G/439G \\
\hline HEINZ SPAGHETTI HOOPS IN TOMATO SCE 400G & OL SPAGHETTI RINGS IN TOMATO SAUCE 410G CAN \\
\hline HEINZ SPAGHETTI \& SAUSAGES 400G CAN & OL SPAGHETTI RINGS \& SAUSAGES 410G-425G CAN \\
\hline BATCHELORS MUSHY PROCESSED PEAS 300G CAN & OL MARROWFAT PROC PEAS 300G \\
\hline MCVITIES RICH TEA BISCUITS 300G & OL RICH TEA FINGER BISCUITS 250G \\
\hline MCVITIES DIGESTIVE BISCUITS 500G & OL DIGESTIVE BISCUITS 500G \\
\hline KELLOGGS CORN FLAKES 500G & OL CORNFLAKES 500G \\
\hline WEETABIX FAMILY SIZE PACKET OF 24 & OL WHEAT BISCUITS 24'S \\
\hline WEETABIX GIANT PACK 48'S & OL WHEAT BISCUITS 48'S \\
\hline KELLOGGS RICE KRISPIES 440G/450G & OL RICE KRISPIES TYPE 440G \\
\hline KELLOGGS CRUNCHY NUT CORNFLAKES 500G & OL HONEY \& NUT CORNFLAKES 500G \\
\hline KELLOGGS RICE KRISPIES 600G & OL RICE KRISPIES TYPE 600G \\
\hline ALPEN ORIGINAL MUESLI 750G & OL SWISS STYLE MUESLI 750G \\
\hline KELLOGGS FROSTIES 500G & OL FROSTED FLAKES 500G \\
\hline KELLOGGS FRUIT N FIBRE 500G & OL FRUIT \& FIBRE BREAKFAST CEREAL 500G \\
\hline FLORA PURE SUNFLOWER OIL 1LT BOTTLE & OL SUNFLOWER COOKING OIL BOTTLE 1LTR \\
\hline BERIO EXTRA VIRGIN OLIVE OIL 500ML & OL EXTRA VIRGIN OLIVE OIL 500ML \\
\hline FILIPPO BERIO MILD \& LIGHT OLIVE OIL 500ML & OL MILD AND LIGHT OLIVE OIL 500ML \\
\hline SAXA TABLE SALT 750G DRUM & OL TABLE SALT 750G \\
\hline BAXTERS CRINKLE CUT BEETROOT 340G & OL PICKLED SLICED BEETROOT 340G \\
\hline HELLMANNS LIGHT MAYONNAISE 200G & OL LIGHT MAYONNAISE 250ML \\
\hline HELLMANNS REAL/ORIG MAYONNAISE JAR 200G & OL MAYONNAISE 250ML JAR ORIGINAL \\
\hline HELLMANNS REAL/ORIG MAYONNAISE JAR 400G & OL MAYONNAISE 500ML (EXC REDUCED CAL) \\
\hline HEINZ SALAD CREAM BOTTLE 285G & OL SALAD CREAM 283G \\
\hline HEINZ TOMATO KETCHUP BOTTLE 340G/342G & OL TOMATO KETCHUP GLASS BOTTLE 325G-340G \\
\hline AMBROSIA CREAMED RICE 425G & OL CRMD RICE PUDDING 420G-439G EXC LOW FAT \\
\hline AMBROSIA LOW FAT CREAMED RICE 425G & OL LOW FAT RICE PUDDING 425G \\
\hline BIRDS INSTANT CUSTARD 75G SACHET & OL INSTANT CUSTARD POWDER 66G-90G SINGLE PK \\
\hline HARTLEYS BEST JAM ANY VARIETY 340G & OL JAM 454G ANY FLAVOUR (EXCEPT STRAWBERRY) \\
\hline DUERRS ENGLISH MARMALADE 454G & OL THICK CUT ORANGE MARMALADE 454G \\
\hline SHIPPAMS SPREAD 75G ANY & OL PASTE'S 75G JAR \\
\hline UNCLE BENS BOIL IN BAG LONG GRAIN RICE 500G & OL EASY COOK BOIL IN BAG RICE 500G \\
\hline UNCLE BENS LONG GRAIN RICE 1KG & OL AMERICAN EASY COOK LONG GRAIN RICE 1KG \\
\hline MCDOUGALLS FLOUR 1.5KG & OL PLAIN/SELF RAISING FLOUR 1.5KG \\
\hline DOMESTOS BLEACH 2 LTR & OL THICK BLEACH 2 LTR \\
\hline FLASH BATHROOM SPRAY 500ML & OL BATHROOM CLEANER TRIGGER 500ML \\
\hline JOHNSONS PLEDGE ANY 250ML & OL FURNITURE POLISH 300ML ANY \\
\hline MR MUSCLE WINDOW CLEANER 500ML TRIGGER & OL WINDOW CLEANER 500ML \\
\hline ST IVEL UTTERLY BUTTERLY 500G & OL BUTTERY TYPE SPREAD 500G \\
\hline COLGATE TOOTHPASTE TOTAL/STRIPE 50ML & OL TOOTHPASTE FRESHMINT 50ML \\
\hline GORDONS DRY LONDON GIN 35CL BOTTLE & OL DRY LONDON GIN 35CL BOTTLE \\
\hline BLACK TOWER 75CL & OL LIEBFRAUMILCH 75CL \\
\hline PEDIGREE CHUM MIXER ANY PACK 2.25KG & OL DOG MIXER 2.5KG \\
\hline NESCAFE INSTANT COFFEE 200G & OL RICH ROAST GRANULES 200G \\
\hline NESCAFE GOLD BLEND INSTANT COFFEE 100G & OL CLASSIC GOLD COFEE 100G \\
\hline NESCAFE DECAF GOLD BLEND COFFEE 100G & OL DECAFF CLASSIC GOLD COFFEE 100G \\
\hline NESCAFE DECAF COFFEE 100G & OL DECAFF RICH ROAST GRANULES 100G \\
\hline R WHITES LEMONADE/DIET LEMONADE 2LT & OL LEMONADE 2LT \\
\hline PEPSI COLA 2 LITRE BOTTLE & OL COLA 2LT \\
\hline TAYLORS YORKSHIRE LEAF TEA 250G & OL PREMIUM LEAF TEA 250G \\
\hline BROOKE BOND PG TIPS PYRAMID 40 TEABAGS 125G & OL PREMIUM TEA BAGS 40'S 125G \\
\hline
\end{tabular}


Table A3. UK private label volume and value shares for product categories in matchedpairs sample, 2004-2008

\begin{tabular}{|c|c|c|c|c|c|c|c|c|c|c|}
\hline NARROW PRODUCT CATEGORY & & $\overline{V O L U}$ & & HARE & & & & & IARE & \\
\hline & 2004 & 2005 & 2006 & 2007 & 2008 & 2004 & 2005 & 2006 & 2007 & 2008 \\
\hline Dairy: blended spreads/butter substitute & 21.5 & 21.4 & 20.1 & 21.5 & 22.6 & 17.4 & 17.2 & 16.5 & 18.4 & 20.3 \\
\hline Breakfast cereals: ready to eat & 32.5 & 33.4 & 35.2 & 34.6 & 36.2 & 26.9 & 26.6 & 27.7 & 27.0 & 28.3 \\
\hline Cookery aids: cooking oils liquid & 73.7 & 72.5 & 73.4 & 72.2 & 72.3 & 64.9 & 63.1 & 65.2 & 66.2 & 70.1 \\
\hline Cookery aids: flour excl cornflour & 57.2 & 56.6 & 56.8 & 60.3 & 64.5 & 40.5 & 39.3 & 39.8 & 43.0 & 47.5 \\
\hline Cookery aids: olive oil & 64.0 & 65.3 & 68.8 & 62.7 & 58.7 & 55.5 & 57.6 & 63.2 & 58.7 & 57.7 \\
\hline Cookery aids: salt table & 52.1 & 57.5 & 60.5 & 58.5 & 57.3 & 32.0 & 35.8 & 37.0 & 34.7 & 33.1 \\
\hline Desserts: custard powder & 34.6 & 31.3 & 44.6 & 40.1 & 43.7 & 23.2 & 15.9 & 17.3 & 15.6 & 10.7 \\
\hline Desserts: milk puddings ca & 56.0 & 59.6 & 59.0 & 54.9 & 56.0 & 41.8 & 41.2 & 41.7 & 38.4 & 40.4 \\
\hline Pasta: canned & 44.9 & 44.7 & 41.3 & 44.3 & 43.5 & 32.1 & 33.2 & 30.7 & 31.7 & 30.7 \\
\hline Pickles: beetroot & 68.5 & 68.5 & 67.8 & 68.3 & 70.8 & 58.1 & 57.0 & 54.5 & 53.8 & 59.2 \\
\hline Preserve & 53.6 & 54.6 & 53.2 & 52.7 & 54.3 & 44.8 & 44.9 & 44.8 & 43.4 & 45.2 \\
\hline Preserves: marmalades & 41.3 & 44.6 & 43.5 & 46.2 & 48.9 & 34.0 & 34.6 & 33.3 & 34.5 & 37.4 \\
\hline Sauces: salad: mayonnaise & 48.3 & 46.9 & 45.9 & 47.4 & 46.1 & 30.9 & 29.1 & 29.8 & 29.8 & 31.2 \\
\hline Sauces: salad: salad & 40.5 & 40.3 & 43.0 & 42.5 & 42.4 & 22.0 & 22.4 & 24.8 & 24.8 & 24.9 \\
\hline Sauces: table: tomato/ketchup & 43.1 & 41.0 & 41.2 & 39.8 & 41.5 & 25.1 & 23.5 & 23.1 & 21.6 & 22.8 \\
\hline Spreads savoury :pastes/spread/pate & 60.1 & 51.9 & 48.2 & 49.2 & 48.2 & 47.6 & 44.1 & 41.9 & 38.7 & 37.2 \\
\hline Veg canned/jar: peas mushy & 67.3 & 62.7 & 61.0 & 52.4 & 51.1 & 53.0 & 51.8 & 54.0 & 48.4 & 47.9 \\
\hline Veg dried: rice & 68.5 & 67.5 & 65.9 & 63.7 & 67.4 & 57.9 & 56.9 & 53.2 & 49.3 & 57.6 \\
\hline Biscuits: sweet: digestives e & 57.3 & 59.7 & 57.6 & 61.1 & 63.8 & 44.9 & 44.9 & 41.5 & 42.5 & 44.2 \\
\hline Biscuits: sweet: tea \& coffee biscuits & 65.9 & 60.8 & 60.5 & 60.5 & 66.3 & 57.6 & 49.9 & 46.1 & 42.9 & 49.0 \\
\hline Drinks-hot: coffee inst excl coffee subst. & 22.6 & 22.5 & 22.9 & 23.2 & 25.9 & 16.6 & 15.2 & 15.4 & 15.7 & 17.4 \\
\hline Drinks-hot: tea bags & 30.8 & 30.4 & 30.3 & 28.5 & 26.9 & 24.6 & 22.8 & 22.8 & 21.4 & 20.8 \\
\hline Drinks-hot: tea packets & 29.1 & 31.0 & 28.5 & 29.9 & 26.2 & 27.0 & 27.6 & 24.8 & 25.6 & 23.0 \\
\hline Drinks-cold: carbonates bottled excl mixers & 42.6 & 42.8 & 46.6 & 46.4 & 44.3 & 25.4 & 24.9 & 26.7 & 26.4 & 25.0 \\
\hline Cakes packaged: fruit pies small & 66.9 & 66.0 & 70.5 & 66.3 & 66.8 & 63.1 & 62.5 & 67.3 & 64.2 & 64.7 \\
\hline Cakes packaged: tarts small & 64.6 & 69.1 & 71.1 & 63.6 & 61.6 & 60.1 & 65.1 & 64.6 & 58.1 & 57.1 \\
\hline Wines: German & 55.1 & 52.9 & 59.4 & 57.8 & 55.8 & 54.1 & 51.8 & 59.3 & 59.1 & 58.8 \\
\hline Gin British & 51.2 & 57.4 & 57.9 & 60.1 & 56.7 & 46.0 & 48.7 & 49.0 & 52.3 & 50.0 \\
\hline H/h-cleaners: bleach & 63.3 & 63.7 & 61.9 & 60.0 & 56.3 & 53.7 & 54.7 & 54.3 & 51.8 & 50.5 \\
\hline H/h-cleaners: multipurpose liquid & 31.7 & 28.6 & 28.8 & 27.7 & 26.4 & 19.9 & 16.6 & 17.2 & 15.3 & 15.3 \\
\hline $\mathrm{H} / \mathrm{h}$-cleaners: polishes floor/furniture & 30.5 & 30.8 & 29.2 & 27.3 & 24.3 & 19.8 & 21.4 & 18.6 & 19.3 & 16.9 \\
\hline H/h-cleaners: window & 27.9 & 35.4 & 38.9 & 33.7 & 32.6 & 22.0 & 27.9 & 30.4 & 24.6 & 24.1 \\
\hline Dog meals/mixers & 28.9 & 28.2 & 31.2 & 32.6 & 36.7 & 21.3 & 19.0 & 20.3 & 19.2 & 22.8 \\
\hline Oral care: toothpastes \& powders & 16.0 & 16.4 & 17.4 & 16.7 & 16.3 & 9.3 & 8.8 & 8.9 & 8.1 & 7.6 \\
\hline TOTAL UK GROCERY MARKET & 41.5 & 41.8 & 43.3 & 43.1 & 47.8 & 38.0 & 37.8 & 39.6 & 39.3 & 43.4 \\
\hline
\end{tabular}

Source: Private Label Manufacturers Association (PLMA) International Private Label Yearbook (various years) 


\section{REFERENCES}

Ailawadi, Kusum, L. and Bari Harlam. 2004. "An Empirical Analysis of the Determinants of Retail Margins: The Role of Store-Brand Share." Journal of Marketing, 68 (1), 147-165.

Ailawadi, Kusum L., Koen Pauwels, and Jan-Benedict E.M. Steenkamp. 2008. "Private-Label Use and Store Loyalty." Journal of Marketing, 72 (6), 19-30.

Armstrong, Mark and John Vickers. 2018. Multiproduct Pricing Made Simple. Journal of Political Economy, forthcoming.

Ball, James. 2009a. “Are the big four playing fair?” The Grocer, 7 February.

Ball, James. 2009b. "Retailers pocket 90\% of promotion profits", The Grocer, 4 April.

Bamford, Vince. 2012. Tesco hopes for Halo effect with femcare venture brand." The Grocer, 16 February.

Bamford, Vince. 2013. What now for Tesco's brave 'venture' brands?" The Grocer, 1 November.

Barsky, Robert, Mark Bergen, Shantanu Dutta, and Daniel Levy. 2001. "What Can the Price Gap between Branded and Private Label Products Tell Us about Markups?" NBER Working Paper W8426, National Bureau of Economic Research, Cambridge MA.

Bell, Richard, Ross Davies, and Elizabeth Howard. 1996. "The Changing Structure of Food Retailing in Europe: The Implications for Strategy." Long Range Planning, 30 (6), 853861.

Benady, David. "Branding does work - shoppers vote with feet after Belgian supermarket removes Unilever products." Brand Republic, 17 February.

Bergès-Sennou, Fabian, Philippe Bontems, and Vincent Réquillart. 2004. "Economics of Private Labels: A Survey of Literature." Journal of Agricultural \& Food Industrial Organization, 2, Article 3.

Bishop, Simon and Mike Walker. 2010. The Economic of EC Competition Law, Third Edition, Sweet \& Maxwell: London.

Bliss, Christopher. (1988). "A Theory of Retail Pricing.” Journal of Industrial Economics, 36 (4), 375-391

Bonfrer, Andre and Pradeep K. Chintagunta. 2004. "Store Brands: Who Buys Them and What Happens to Retail Prices When They Are Introduced?" Review of Industrial Organization, 24, 195-218.

Chakraborty, Ratula, Paul W. Dobson, Jonathan S. Seaton and Michael Waterson. 2014. "Market Consolidation and Pricing Developments in Grocery Retailing: A Case Study," in Analysis of Competition Policy and Sectoral Regulation, Martin Pietz and Yossi Spiegel (ed.), Now Publishers, 3-29.

Chakraborty, Ratula, Paul W. Dobson, Jonathan S. Seaton and Michael Waterson. 2015. "Pricing in Inflationary Times: The Penny Drops." Journal of Monetary Economics, 76, 71-86.

Chintagunta, Pradeep K. 2002. "Investigating Category Pricing Behavior at a Retail Chain." Journal of Marketing Research, 39 (2), 141-154. 
CHOICE 2014. "Supermarket special investigation: Australia's big two supermarkets put the price squeeze on suppliers and brands." (https://www.choice.com.au/shopping/everydayshopping/supermarkets/articles/choice-supermarket-special - accessed 6/3/2018)

CMA 2015. Pricing Practices in the Groceries Market: Response to a super-complaint made by Which? on 21 April 2015, Competition and Markets Authority, London.

Coelho do Vale, Rita, Pedro Verga Matos and Jorge Caiado. 2016. "The impact of private labels on consumer store loyalty: An integrative perspective." Journal of Retailing and Consumer Services, 28, 179-188.

Competition Commission. 2000. Supermarkets: A report on the supply of groceries from multiple stores in the United Kingdom, Cm 4842, TSO: London.

Competition Commission. 2003. Safeway plc and Asda Group Limited (owned by Wal-Mart Stores Inc); Wm Morrison Supermarkets PLC; J Sainsbury plc; and Tesco plc: A report on the mergers in contemplation, $\mathrm{Cm}$ 5950, TSO: London.

Competition Commission. 2008. Groceries Market Investigation - Final Report, April.

Corstjens, Marcel and Rajiv Lal. 2002. "Building Store Loyalty Through Store Brands." Journal of Marketing Research, 37 (August), 281-291.

Dhar, Sanjay K. and Stephen J. Hoch. 1997. "Why Store Brand Penetration Varies by Retailer." Marketing Science, 16 (3), 208-227.

Dobson, Paul W. 1998. "The Economic Welfare Implications of Own Label Products School of Management." University of Nottingham Discussion Paper 1998.IV.

Dobson, Paul W. 2005. "Exploiting Buyer Power: Lessons from the British Grocery Trade." Antitrust Law Journal, 72 (2), 529-562.

Dobson, Paul W. and Ratula Chakraborty. 2009. "Private Labels and Branded Goods: Consumers' 'Horrors' and 'Heroes'," in Private Labels, Brands and Competition Policy: The Changing Landscape of Retail Competition, Ariel Ezrachi and Ulf Bernitz (eds.), Oxford University Press: Oxford, 99-124.

Dobson, Paul W. and Ratula Chakraborty. 2014. "How Do National Brands And Store Brands Compete?" CCP Working Paper 14-7, Centre for Competition Policy.

Dobson, Paul W. and Li Zhou. 2014. "The Competition Effects of Lookalike Private Label Products," in National Brands and Private Labels in Retailing (First International Symposium NB\&PL, Barcelona, June 2014), J.C. Gázquez-Abad, F.J. Martínez-López, I. Esteban-Millat, and J.A. Mondéjar-Jiménez (eds.), Springer Proceedings in Business and Economics, Heidelberg, 17-26.

Economist. 2015. Buying up the shelves. The Economist, 18 June.

Ellickson, Paul D., Pianpian Kong, and Mitchell J. Lovett. 2017. "Private Labels and Retailer Profitability: Bilateral Bargaining in the Grocery Channel.” Working paper.

Ezrachi, Ariel and Jonathan Reynolds. 2009. "Advertising, Promotional Campaigns, and Private Label," in Private Labels, Brands and Competition Policy: The Changing Landscape of Retail Competition, Ariel Ezrachi and Ulf Bernitz (eds.), Oxford University Press: Oxford, 259-279.

Fernandez Nogales, A. and Monica Gomez Suarez. 2005. "Shelf space management of private labels: a case study in Spanish retailing." Journal of Retailing and Consumer Services, 12 (3), 205-216. 
Gallagher, Julie. 2008. "Private Promos.” Supermarket News, 22 December.

Gates, Kelly. 2007. "Publix Kicks Off Bold PL Promotion.” Supermarket News, 23 April.

Gates, Kelly. 2008. "Private Takeover." Supermarket News, 3 November.

González-Benito, Óscar and Mercedes Martos-Partal. 2012. "Role of Retailer Positioning and Product Category on the Relationship between Store Brand Consumption and Store Loyalty." Journal of Retailing, 88 (2), 236-249.

Grew, Joanne. 2009. "Switch and Save sampling campaign branded unfair." The Grocer, 17 October.

Halliwell, James. 2015. "Copycats: going to war with the packaging lookalikes." The Grocer, 23 January.

Hickman, Martin. 2009. "Tesco in probe over 'cut-price' drink offer." The Independent, 6 January.

Hoch, Stephen J. and Shumeet Banerji. 1993. "When Do Store Brands Succeed?" Sloan Management Review, 34 (4), 57-67.

Hurd, Charles W. and M. Zimmerman. 1914. "How the Chains Are Taking Over the Retail Field - IV." Printers' Ink, 8 October, 36-42.

Kim, Namwoon and Philip M. Parker. 1999. "Collusive conduct in private label markets." International Journal of Research in Marketing, 16 (2), 143-155.

Kumar, Nirmalya and Jan-Benedict E.M. Steenkamp. 2007. Private Label Strategy: How to Meet the Store Brand Challenge, Harvard University Press: Cambridge MA.

Lal, Rajiv. 1990. "Price Promotions: Limiting Competitive Encroachment." Marketing Science, 9 (3), 247-262.

Lamey, Lien, Barbara Deleersnyder, Jan-Benedict E.M. Steenkamp, Marnik G. Dekimpe. 2012. "The Effect of Business-Cycle Fluctuations on Private-Label Share: What Has Marketing Conduct Got to Do with It?” Journal of Marketing, 76 (1), 1-19.

Lan, Hao and Paul W. Dobson. 2017. "Healthy competition to support healthy eating? An investigation of fruit and vegetable pricing in UK supermarkets." Journal of Agricultural Economics, 68 (3), 881-900.

Leyland, Adam. 2006. "Asda tests brand equity.” The Grocer, 27 May.

Leyland, Adam, James Ball and Chloe Smith. 2008. "Suppliers shocked as own-label blitz launched on brands." The Grocer, 6 September.

Lodish, Len, and Carl F. Mela. 2007. "If brands are built over years, why are they managed over quarters?" Harvard Business Review, 85 (7-8), July-August, 104-12.

Mazumdar, Tridib, S.P. Raj and Indrajit Sinha. 2005. Reference Price Research: Review and Propositions. Journal of Marketing, 69 (October), 84-102.

Meza, Sergio and K. Sudhir. 2010. "Do Private Labels Increase Retailer Bargaining Power?" Quantitative Marketing and Economics, 8, 333-363.

Mintel. 2009. Brands - Are Supermarkets Squeezing Out Brands? - UK - February 2009, Mintel International Group Limited, February.

Narasimhan, Chakravarthi and Ronald T. Wilcox. 1998. "Store Brands and Channel Relationship: A Cross-Category Analysis.” Journal of Business, 71 (4), 573-600. 
Nielsen. 2009. State of the Nation, Nielsen Company, April.

Nielsen. 2014. The State of Private Label around the World, Nielsen Company, November.

Olbrich, Rainer and Carl-Christian Buhr. 2005. "Who benefits from the prohibition of resale price maintenance in European competition law? The case of food retailing." European Competition Law Review, 26 (12), 705-713.

Olbrich, Rainer and Gundula Grewe. 2013. "Proliferation of private labels in the groceries sector: The impact on category performance." Journal of Retailing and Consumer Services, 20 (2), 147-153.

Olbrich, Rainer, Gundula Grewe, and Ruth Orenstrat. 2009. "Private Labels, Product Variety, and Price Competition - Lessons from the German Grocery Sector," in Ariel Ezrachi and Ulf Bernitz (eds.) Private Labels, Brands and Competition Policy: The Changing Landscape of Retail Competition, Oxford University Press: Oxford, 235-257.

Palmer, Daniel. 2009. "Australian supermarkets strengthen private label push." Australian Food News, 21 May (http://www.ausfoodnews.com.au/2009/05/21/australiansupermarkets-strengthen-private-label-push.html - accessed 6/3/2018).

Pauwels, Koen and Shruba Srinivasan. 2004. "Who benefits from store brand entry?" Marketing Science, 23, 364-390.

Pauwels, Koen and Shruba Srinivasan. 2009. "Pricing of National Brands versus Store Brands: Market Power Components, Findings and Research Opportunities," in Vithala R. Rao (ed.) Handbook of Pricing Research in Marketing, Edward Elgar: Cheltenham, 258-282.

Perkins, Carla. 2017a. "Big brands count the cost as Sainsbury's declares war." The Grocer, 23 June.

Perkins, Carla. 2017b. "Oils: own label oils beat brands as prices soar." The Grocer, 15 December.

Perloff, Jeffrey M., Jeffrey T. LaFrance and Hayley H. Chouinard. 2012. "Brand name and private label price setting by a monopoly store." Economics Letters, 116 (3), 508-511.

Poulter, Sean. 2009. “Shoppers 'conned' by copycat brands.” Daily Mail, 11 May.

Quinn, Ian. 2016a. “Asda's Project Renewal taxes axe to leading brands.” The Grocer, 10 June.

Quinn, Ian. 2016b. “Own label front and centre in Tesco's new store layouts.” The Grocer, 18 August.

Quinn, Ian. 2017. "Copycat packaging tricking 'autopilot' shoppers into making purchases." The Grocer, 17 August.

Raju, Jagmohan, Raj Sethurman, and Sanjay K. Dhar. 1995. "The Introduction and Performance of Store Brands.” Management Science, 41 (6), 957-978.

Sayman, Serdar, Stephen J. Hoch and Jagmohan S. Raju. 2002. "Positioning of Store Brands." Marketing Science, 21 (4), 378-397.

Sayman, Serdar and Jagmohan S. Raju. 2004. "Investigating the Cross-Category Effects of Store Brands." Review of Industrial Organization, 24 (2), 129-141.

Sayman, Serdar and Jagmohan S. Raju. 2007. "Store Brands: Back to the Future," in Review of Marketing Research, Volume 3, Naresh K. Malhotra (ed.), M.E. Sharp, 132-151.

Scott Morton, Fiona and F. Zettelmeyer. 2004. "The Strategic Positioning of Store Brands in Retailer-Manufacturer Negotiations.” Review of Industrial Organization, 24, 61-194. 
Seenivasan, Satheesh, K. Sudhir, and Debabrata Talukdar. 2016 "Do Store Brands Aid Store Loyalty?" Management Science, 62 (3), 802-816.

Sethuraman, Raj. 2009. "Assessing the External Validity of Analytical Results from National Brand and Store Brand Competition Models.” Marketing Science, 28 (4), 759-781.

Sethuraman, Raj and Katrijn Gielens. 2014. "Determinants of Store Brand Share." Journal of Retailing, 90 (2), 141-153.

Sethuraman, Raj and Jagmohan S. Raju. 2012. "Private label strategies: myths and realities," in Venkatesh Shankar and Gregory S. Carpenter (eds), Handbook of Marketing Strategy, Cheltenham: Edward Elgar, 318-355.

Smith, Chloe. 2009. “'Cheesegrater' Blackhurst to slice 10 more categories.” The Grocer, 28 February.

Soberman, David A. and Philip M. Parker. 2006. "The economics of quality-equivalent store brands." International Journal of Marketing Research, 23, 125-139.

Steenkamp Jan-Benedict E.M., Harald J. Van Heerde, Inge Geyskens. 2010. "What Makes Consumers Willing to Pay a Price Premium for National Brands over Private Labels?" Journal of Marketing Research, 47 (6), 1011-1024.

Steiner, Robert L. 2004. "The Nature and Benefits of National Brand/Private Label Competition." Review of Industrial Organization, 24 (2), 105-127.

Steiner, Robert L. 2009. "Market Power in Consumer Goods Industries," in in Private Labels, Brands and Competition Policy: The Changing Landscape of Retail Competition, Ariel Ezrachi and Ulf Bernitz (eds.), Oxford University Press: Oxford, 73-98.

Stores. 2018. "Retailers increasingly use their own brands to stand out from the competition." Stores Magazine, 26 February (https://stores.org/2018/02/26/the-rebirth-of-private-label/ - accessed 6/3/2018).

Sudhir, K. and Debabrata Talukdar. 2004. "Does Store Brand Patronage Image Store Patronage?" Review of Industrial Organization, 24 (2), 143-160.

Tarnowski, Joseph. 2004. "Invasion of privacy." Progressive Grocer, 1 November.

Thomassen, Øyvind, Howard Smith, Stephan Seiler and Pasquale Schiraldi. 2017. "Multicategory competition and market power: a model of supermarket pricing." American Economic Review, 107 (8), 2308-2351.

Vogel, Mike. 2004. "Drug chains give store brands that extra little push." Chain Drug Review, 25 October.

Walters, Rockney G. and Heikki J. Rinne. 1986. "An Empirical Investigation into the Impact of Price Promotions on Retail Store Performance.” Journal of Retailing, 62 (3), 237-266.

Ward, Michael B., Jay P. Shimshack, Jeffrey M. Perloff and J. Michael Harris. 2002. "Effects of the Private-Label Invasion in Food Industries." American Journal of Agricultural Economics, 84 (4), 961-973.

Wildenbeest, Matthijs R. 2011. An empirical model of search with vertically differentiated products. Rand Journal of Economics, 42 (4), 729-757.

Wolinsky, Asher. 1987. "Brand Names and Price Discrimination." Journal of Industrial Economics, 35 (3), 255-268. 